\title{
Alternative Treatment Strategies for Secondary Bacterial and Fungal Infections Associated with COVID-19
}

\author{
Ritam Das (D) $\cdot$ Komal Kotra · Pulkit Singh · Belinda Loh • \\ Sebastian Leptihn · Urmi Bajpai
}

Received: June 23, 2021 / Accepted: October 21, 2021 / Published online: November 22, 2021

(C) The Author(s) 2021, corrected publication 2021

\begin{abstract}
Antimicrobials are essential for combating infectious diseases. However, an increase in resistance to them is a major cause of concern. The empirical use of drugs in managing COVID19 and the associated secondary infections have further exacerbated the problem of
\end{abstract}

Ritam Das, Komal Kotra and Pulkit Singh contributed equally to this work.

R. Das

Department of Life Science, Acharya Narendra Dev College, University of Delhi, New Delhi 110019, India

e-mail: ritamdas007@gmail.com

K. Kotra $\cdot$ P. Singh

Department of Zoology, Acharya Narendra Dev College, University of Delhi, New Delhi 110019, IndiaK. Kotra

e-mail: komalkotra1@gmail.comP. Singh

e-mail: pulkitsinghims@gmail.com

B. Loh · S. Leptihn

Department of Infectious Diseases, Sir Run Run

Shaw Hospital, Zhejiang University School of

Medicine, Hangzhou 314400, People's Republic of

ChinaB. Loh

e-mail: belinda.loh@intl.zju.edu.cnS. Leptihn

e-mail: leptihn@intl.zju.edu.cn

U. Bajpai $(\bowtie)$

Department of Biomedical Science, Acharya

Narendra Dev College, University of Delhi,

Govindpuri, Kalkaji, New Delhi 110019, India

e-mail: urmibajpai@andc.du.ac.in antimicrobial resistance. Hence, the situation mandates exploring and developing efficient alternatives for the treatment of bacterial and fungal infections in patients suffering from COVID-19 or other viral infections. In this review, we have described the alternatives to conventional antimicrobials that have shown promising results and are at various stages of development. An acceleration of efforts to investigate their potential as therapeutics can provide more treatment options for clinical management of drug-resistant secondary bacterial and fungal infections in the current pandemic and similar potential outbreaks in the future. The alternatives include bacteriophages and their lytic enzymes, anti-fungal enzymes, antimicrobial peptides, nanoparticles and small molecule inhibitors among others. What is required at this stage is to critically examine the challenges in developing the listed compounds and biomolecules as therapeutics and to establish guidelines for their safe and effective application within a suitable time frame. In this review, we have attempted to highlight the importance of rational use of antimicrobials in patients suffering from COVID-19 and boost the deployment of alternative therapeutics.

Keywords: Antimicrobial peptides; Bacteriophage; COVID-19; Drug repurposing; Nanoparticles; Secondary infections 


\section{Key Summary Points}

Exaggerated usage of antimicrobials in the management of COVID-19 has aggravated the phenomenon of antimicrobial resistance (AMR)

There is an urgent need for alternative antimicrobials. Studies that have demonstrated the effectiveness of several alternatives against drug-resistant bacterial and fungal infections have been highlighted in this study

The alternatives include inorganic nanoparticles, bacteriophages, repurposed drugs, antimicrobial enzymes, peptides and small molecules

To explore diverse approaches to deal with the microbial infections is imperative given a continuous rise in the ineffectiveness of traditional antimicrobials

\section{INTRODUCTION}

The current outbreak of the novel coronavirus SARS-CoV-2 (severe acute respiratory syndrome coronavirus 2) has taken over 4 million lives worldwide (as of 1 October 2021, WHO) (https://covid19.who.int/). Disease morbidity and mortality of patients around the globe are a matter of grave concern. In such viral outbreaks, while treatment of the primary disease is critical, attention to secondary bacterial and fungal infections is as imperative, especially if they are drug-resistant. As witnessed during the epidemics of viral infections in the past 2 decades, a large percentage of patients' deaths occurred because of drug-resistant secondary microbial infections [1]. Emerging reports have demonstrated that $90 \%$ of the COVID-19 patients have received antibiotic therapy though only a few actually required them. This impractical and empirical use of antibiotics further aggravates the antibiotic-resistance crisis we are facing today [1-3]. Hence, it is of paramount importance to assess the morbidity due to secondary infections, to consider alternative clinical approaches to currently deployed therapeutics and to accelerate their research and development (Fig. 1).

The successful launch of several vaccines within a year has given us enough reasons to rethink the timelines. In this review, we discuss the alternative treatment strategies to target secondary infections caused by fungal or bacterial pathogens in COVID-19 patients. We also highlight the potential of antimicrobial strategies that we believe mandates further investigation (Table 1).

\section{AIM AND METHODOLOGY}

The study aims to present the secondary bacterial and fungal infections in patients suffering from COVID-19 that show high levels of antimicrobial resistance. We have attempted to summarize the various antimicrobial alternatives to treat the secondary infections, which are currently at various stages of research and development, and highlight their importance in preparedness for future pandemics. For a period of 5 months (October 2020-March 2021) the authors of this study performed a PubMed search using various combinations of the keywords: (1) COVID-19, (2) secondary infections, (3) bacterial and fungal infections, (4) antibiotic resistance, (5) antifungal resistance, (6) alternative therapeutic strategies and (7) novel molecules. Different research topics were assigned to the authors to generate a narrative review. The authors then retrieved full texts of the relevant papers and discussed and prepared separate drafts according to their topic. These drafts were merged into a final manuscript consisting of 9 figures, 4 tables and 161 references. The final manuscript was proofread and approved by all the authors of this study.

This article is based on previously conducted studies and does not contain any new studies with human participants or animals performed by any of the authors. 


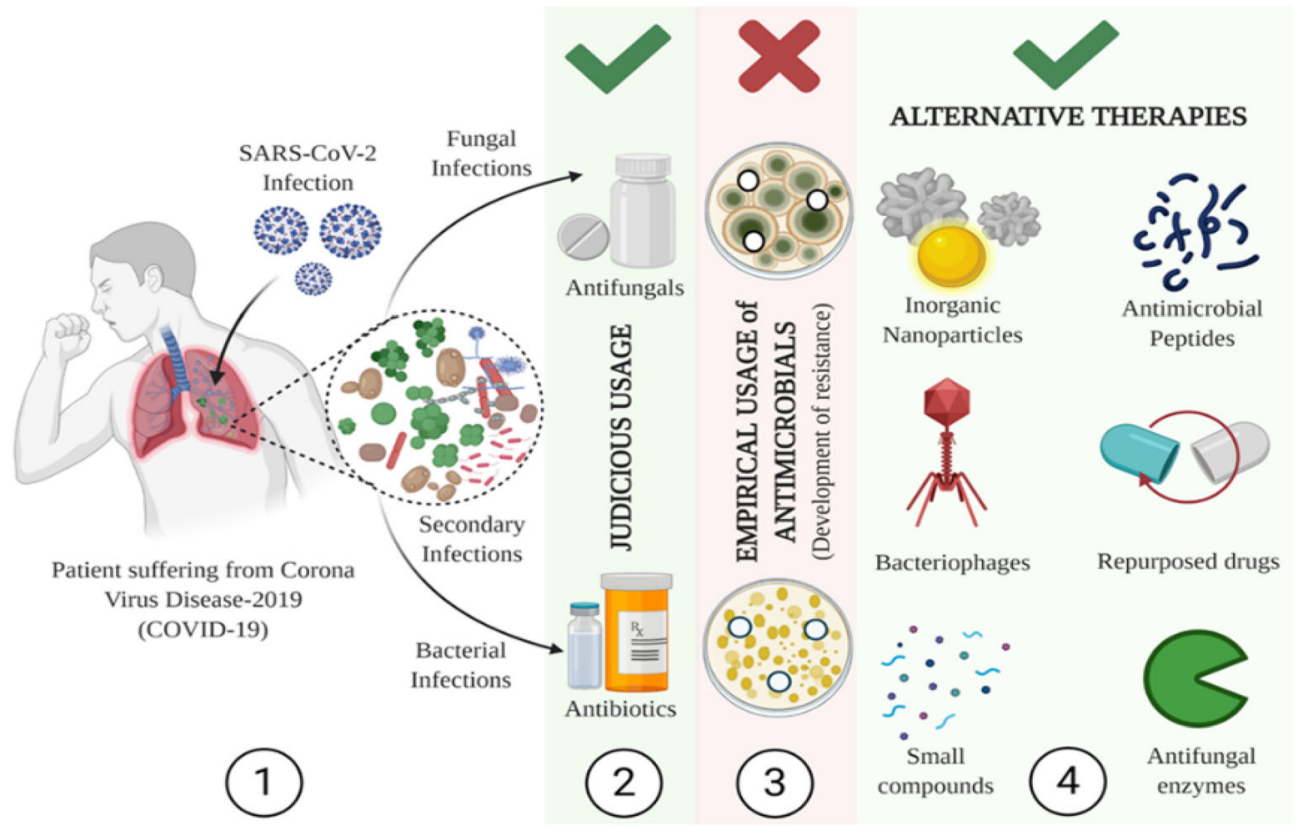

Fig. 1 Schematic representation of drug-resistant secondary infections in SARS-CoV-2-infected patients and the possible alternative therapies. (1) A patient suffering from COVID-19 and other bacterial and fungal secondary infections. (2) Current treatment regimen for secondary infections. (3) Empirical prescriptions and non-compliance

with the prescribed antimicrobial course exacerbate the problem of drug resistance. (4) The untapped alternative therapeutic options available that can help combat drug resistance and treat infections

Table 1 Objectives and summary of the review

\begin{tabular}{|c|c|c|}
\hline Why & this study? & \\
\hline $\begin{array}{l}\text { The mortality and morbidity rate due } \\
\text { to secondary infections associated } \\
\text { with COVID-19 is immense. The } \\
\text { impractical use of antibiotics has laid } \\
\text { down a perfect foundation for the } \\
\text { development of drug-resistant } \\
\text { pathogens }\end{array}$ & $\begin{array}{l}\text { We have identified and overviewed } \\
\text { several strategies that have the } \\
\text { potential to be used against bacterial } \\
\text { and fungal infections during } \\
\text { COVID-19 }\end{array}$ & $\begin{array}{l}\text { Heavy reliance on traditional methods } \\
\text { of targeting microbes and ignorance } \\
\text { about innovations has led to the } \\
\text { phenomenon of drug resistance. This } \\
\text { study is a culmination of several } \\
\text { alternate ways we can deal with this } \\
\text { situation that mandates further } \\
\text { analysis }\end{array}$ \\
\hline $\begin{array}{l}\text { Dur narrative highlights the other } \\
\text { effective therapies that can be } \\
\text { introduced against these drug- } \\
\text { resistant pathogens. This different } \\
\text { perspective of the treatment of } \\
\text { resistant pathogens is a bypass for th } \\
\text { way we see medicine }\end{array}$ & $\begin{array}{l}\text { The study describes the possible } \\
\text { therapeutic applications of these } \\
\text { alternate strategies by illustrating the } \\
\text { various ways in which they were used } \\
\text { successfully in in vitro and in vivo } \\
\text { experiments against drug-resistant } \\
\text { pathogens }\end{array}$ & $\begin{array}{l}\text { Antibiotics will always be the } \\
\text { underpinning of modern medicine; } \\
\text { however, strategies described in this } \\
\text { review can be an instrumental way to } \\
\text { develop better therapeutic options. A } \\
\text { multifaceted approach is always } \\
\text { better than a direct one }\end{array}$ \\
\hline
\end{tabular}




\section{SECONDARY BACTERIAL INFECTIONS AMONG COVID-19 PATIENTS}

Secondary microbial infections in the respiratory tract are a common phenomenon in patients suffering from severe acute respiratory syndrome coronavirus 2 (SARS-CoV-2) and contribute significantly to high morbidity and mortality rates [1]. Opportunistic infections with bacterial and fungal pathogens often manifest as superinfections and are acquired mostly in hospitals. About $50 \%$ of the nonsurviving patients suffering from COVID-19 have been reported to contract a bacterial infection, yet the required strategy to manage these infections in COVID-19 cases is not in place yet $[4,5]$.

An observational study on 52 critically ill patients with COVID-19 showed 7 subjects to have hospital-acquired infections and 4 out of those to have died because of infection. In another study done on the deceased patients, sepsis was found to have occurred in all the subjects $(113 / 113)[6,7]$. A plethora of bacterial pathogens are reported to cause these infections including Acinetobacter baumannii, Enterococcus faecium, Streptococcus pneumoniae, Klebsiella pneumoniae, Enterobacter cloacae, Haemophilus influenzae and Pseudomonas aeruginosa. Metagenomic next-generation sequencing analysis of urine, catheters, lower respiratory and blood samples demonstrated 22 out of 38 (57.89\%) patients had secondary bacterial infections with gram-negative bacteria being the most detected pathogens $(50 \%)[8,9]$. In a study done in a city in Iran, all 19 patients admitted to ICU were found to be infected with $A$. baumannii (90\%) and Staphylococcus aureus (10\%) [10]. These reports highlight the high occurrence of secondary infections in patients suffering from the novel coronavirus disease and the urgent requirement for reliable preventive measures and solutions.

\section{Antimicrobial Resistance in Secondary Infections}

The complexity of diagnosis and treatment of secondary infections in patients with COVID-19 is a major issue that has propelled the empirical use of antibiotics [11]. Patients with invasive mechanical ventilation are prone to hospital and ventilator-acquired infections and therefore are given antibiotics [12]. A study on hospitalized patients found that $72 \%(1450 / 2010)$ of the patients received antibiotic treatment while only $8 \%(62 / 806)$ actually had any bacterial or fungal infections. This excessive use of antibiotics is further exacerbating the antimicrobial resistance menace $[3,13]$. While some bacteria are naturally resistant to antibiotics, others can acquire resistance through chromosomal mutations (such as insertions and deletions) and horizontal gene transfer via transformation, conjugation or transduction by temperate phages $[14,15]$. The resistance phenomenon however can increase rapidly on over-prescription of antibiotics [16]. Epidemiological studies have also illustrated a direct relationship between antibiotic use and the development and dissemination of drug-resistant pathogens $[17,18]$. A worldwide increase in Enterobacterales producing carbapenemase (such as K. pneumoniae and E. cloacae) and clinical isolates of multiple and extremely drug-resistant strains (MDR and XDR) of $A$. baumannii and $P$. aeruginosa have been reported recently [19]. A similar trend was also observed in the high-risk clones (HiRCs) of (ST)131 Escherichia coli and ST258, ST307 and ST11 K. pneumoniae, which have developed effective resistance mechanisms against even the new antibiotics such as aminoglycoside and polymyxins [20]. Bacterial resistance to existing antibiotics has therefore threatened the underpinning of modern medicine, and the current pandemic caused by SARS-CoV2 may also have accelerated the cause and spread of antimicrobial resistance [3]. Hence, in this study, we have attempted to identify some of the effective 
alternatives to antibiotics that appear promising to mitigate this global menace. We believe that by evaluating other antimicrobial solutions which could perhaps be leveraged for treating secondary infections in COVID-19 patients, indiscriminate use of antibiotics can also be curtailed (Table 2).

Table 2 Features of other alternative approaches proposed in this review

\begin{tabular}{|c|c|c|c|c|c|}
\hline Features & Antibiotics & Inorganic NPs & Phages & Phage lysins & Repurposed drugs \\
\hline esista & $\begin{array}{l}\text { Bacterial } \\
\text { pathogens can } \\
\text { develop } \\
\text { resistance to } \\
\text { antibiotics [18] }\end{array}$ & $\begin{array}{l}\text { The diversity in the } \\
\text { action of NPs } \\
\text { indicates fewer } \\
\text { chances of } \\
\text { bacterial } \\
\text { resistance }[138]\end{array}$ & $\begin{array}{l}\text { Resistance against } \\
\text { lytic phages is rare } \\
{[139]}\end{array}$ & $\begin{array}{l}\text { Resistance } \\
\text { against lysins } \\
\text { appears bleak } \\
{[140]}\end{array}$ & $\begin{array}{l}\text { If resistance } \\
\text { develops, the } \\
\text { same approach } \\
\text { could help us } \\
\text { discover new } \\
\text { drug candidates }\end{array}$ \\
\hline Specificity & $\begin{array}{l}\text { Antibiotics are of } \\
\text { both broad and } \\
\text { narrow ranges } \\
{[18]}\end{array}$ & $\begin{array}{l}\text { They are generally } \\
\text { of a broad range } \\
{[138]}\end{array}$ & $\begin{array}{l}\text { Phages are highly } \\
\text { specific [45] }\end{array}$ & $\begin{array}{l}\text { Lysins are specific } \\
\text { for a target } \\
{[141]}\end{array}$ & $\begin{array}{l}\text { Repurposed drugs } \\
\text { are mostly of } \\
\text { broad-spectrum } \\
{[70]}\end{array}$ \\
\hline Availability & $\begin{array}{l}\text { Antibiotics are } \\
\text { tougher to } \\
\text { formulate and } \\
\text { produce [142] }\end{array}$ & $\begin{array}{l}\text { NPs can be } \\
\text { prepared readily } \\
\text { and studied } \\
\text { against any } \\
\text { pathogens [143] }\end{array}$ & $\begin{array}{l}\text { Phages against any } \\
\text { pathogenic } \\
\text { bacteria can be } \\
\text { isolated }[45]\end{array}$ & $\begin{array}{l}\text { Endolysins have a } \\
\text { moderate } \\
\text { discovery rate } \\
{[141]}\end{array}$ & $\begin{array}{l}\text { Repurposed drugs } \\
\text { are mostly FDA- } \\
\text { approved drugs } \\
\text { that are readily } \\
\text { available [144] }\end{array}$ \\
\hline Efficiency & $\begin{array}{l}\text { Antibiotics are } \\
\text { efficient against } \\
\text { both types of } \\
\text { bacteria [145] }\end{array}$ & $\begin{array}{l}\text { NPs have efficient } \\
\text { antimicrobial } \\
\text { activity against } \\
\text { both bacteria and } \\
\text { fungi }[146,147]\end{array}$ & $\begin{array}{l}\text { Phages have been } \\
\text { reported to be } \\
\text { effective against } \\
\text { both types of } \\
\text { bacteria [148] }\end{array}$ & $\begin{array}{l}\text { Lysins are also } \\
\text { reported to be } \\
\text { effective } \\
\text { against both } \\
\text { types of } \\
\text { bacteria [149] }\end{array}$ & $\begin{array}{l}\text { Can be highly } \\
\text { effective against } \\
\text { various bacterial } \\
\text { pathogens } \\
{[70,150]}\end{array}$ \\
\hline $\begin{array}{l}\text { Environmental } \\
\text { impact }\end{array}$ & $\begin{array}{l}\text { Non-essential } \\
\text { usage of } \\
\text { antibiotics can } \\
\text { affect } \\
\text { downstream } \\
\text { environments } \\
{[151]}\end{array}$ & $\begin{array}{l}\text { Excessive use of } \\
\text { NPs can affect } \\
\text { health and } \\
\text { environmental } \\
\text { conditions [152] }\end{array}$ & $\begin{array}{l}\text { Being composed of } \\
\text { protein and } \\
\text { nucleic acid, } \\
\text { phages have a low } \\
\text { environmental } \\
\text { impact }[153]\end{array}$ & $\begin{array}{l}\text { No reported } \\
\text { significant } \\
\text { environmental } \\
\text { impact }\end{array}$ & $\begin{array}{l}\text { Excessive usage of } \\
\text { even repurposed } \\
\text { drugs can affect } \\
\text { downstream } \\
\text { environments } \\
{[154]}\end{array}$ \\
\hline Commerciality & $\begin{array}{l}\text { The cost of } \\
\text { developing a } \\
\text { new antibiotic } \\
\text { is quite high } \\
{[155]}\end{array}$ & $\begin{array}{l}\text { Synthesis of NPs is } \\
\text { quite simple and } \\
\text { cost-effective } \\
{[156]}\end{array}$ & $\begin{array}{l}\text { Isolation and } \\
\text { pharmaceutical } \\
\text { production of } \\
\text { phages is relatively } \\
\text { economic [153] }\end{array}$ & $\begin{array}{l}\text { The cost of lysin } \\
\text { production is } \\
\text { high [141] }\end{array}$ & $\begin{array}{l}\text { Repurposed drugs } \\
\text { usually } \\
\text { circumvent the } \\
\text { cost of new drug } \\
\text { formulation } \\
\text { [144] }\end{array}$ \\
\hline
\end{tabular}




\section{SECONDARY FUNGAL INFECTIONS AMONG COVID-19 PATIENTS}

Fungal infections contribute heavily to human fatality, yet their role is not well recognized [21]. A retrospective study of SARS and influenza virus from China and worldwide suggests that COVID-19 patients, especially those who are severely ill and immunocompromised, are at a greater risk of suffering from invasive mycoses. Effective treatment and life-saving operations would require proper detection and responsible treatment of the secondary fungal infections [22].

Age and SOFA (sequential organ failure) scores are some of the most influential prognostic factors being monitored in COVID-19 patients. Other vital factors for the said disease are pre-existing diabetes and chronic ailments such as obesity, hypertension and chronic lung disease, etc. [5]. Although the presence of bacterial and/or fungal co-infection is an important and explicit factor affecting mortality, it has not received the appropriate clinical attention [23]. Diagnosis of COVID-19 in patients along with viral pneumonia is often escalated by secondary infections, which have contributed extensively to the inflating the mortality rate. According to a cohort study [9], 20 of the 90 SARS patients had infections involving the lower respiratory tract in 2003, which summed up to nearly $70.6 \%$ of SARS patients who were critically ill. Of these infections, the most common pathogenic agents were gram-negative bacteria and the fungi Candida. Other common secondary infections include mucormycosis, aspergillosis and cryptococcosis [22].

\section{Fungicide Resistance in Primary and Secondary Fungal Infections}

Heavy and unregulated use of fungicides has increased the incidence of invasive mycoses, which are resistant to several fungicides (Fig. 2). This has been noticed in both plant pathogenic fungi and strains that affect human health [24]. The effects of such non-judicious use are explicit in critically ill patients. In a cohort of 31 patients, $19.4 \%$ were found to be suffering from

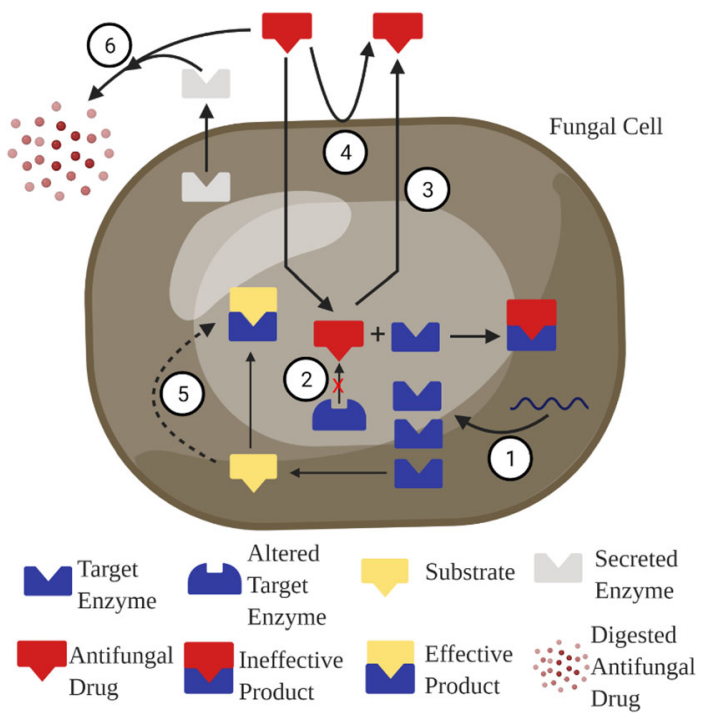

Fig. 2 Mechanisms of resistance in fungi against antifungal compounds. (1) Fungi tend to overproduce enzymes that are targeted by azoles and other drugs. This prevents the inhibition of vital biochemical reactions. (2) Altering the spatial structure of the targeted enzyme reduces the binding efficiency of azole exponentially. This is a classic case of enzyme-substrate mismatch. (3) Azoles and antifungal drugs are actively pumped out of the cell with the help of efflux pumps. (4) The drugs are not able to penetrate the fungal cell wall/membrane. (5) The cell bypasses the conventional pathway that the drug aims to target. (6) The fungal cells secrete extracellular enzymes that degrade the antifungal compounds

aspergillosis [25]. Recent studies conducted in hospitals in India dedicated to the treatment of COVID-19 reported candidemia to affect approximately $2.5 \%$ of the critically ill patients, of which 53\% died. Additionally, $66 \%$ of patients who died were experiencing persistent fungemia despite having been treated with antifungal medication [26]. Oral triazole therapy has been established as the gold standard for the treatment of fungal infections and has been in use clinically for many years. However, a study conducted a decade ago by Denning et al. reported a high frequency of triazole resistance in non-culturable Aspergillus fumigatus in patients suffering from chronic fungal diseases (Fig. 2) [27]. Failure of common and traditional methods of therapy calls for examining the non-traditional solutions (Table 3). 
Table 3 Comparison of various features of antifungal drugs with the other alternative antifungal therapies proposed in this review

\begin{tabular}{|c|c|c|c|c|}
\hline Features & Antifungal drugs & Antifungal enzymes & Antifungal peptides & Repurposed drugs \\
\hline Name & $\begin{array}{l}\text { Azoles } \\
\qquad[27,113,114]\end{array}$ & $\begin{array}{l}\text { Chitotriosidases, } \\
\text { lactoferrins, } \\
\text { antileukoproteases } \\
\text { and lysozymes } \\
{[86,92,98,157]}\end{array}$ & $\begin{array}{l}\text { Defensins, cathelicidins, } \\
\text { dermicidins, hGAPDH, } \\
\text { synthetic peptides } \\
{[117,111,122-124]}\end{array}$ & $\begin{array}{l}\text { Haloperidol, anti- } \\
\text { inflammatory drugs, } \\
\text { atorvastatin } \\
{[74,76,81]}\end{array}$ \\
\hline $\begin{array}{l}\text { Tested on } \\
\text { fungi }\end{array}$ & $\begin{array}{l}\text { Have been long in } \\
\text { use and } \\
\text { developed for } \\
\text { every potentially } \\
\text { pathogenic } \\
\text { fungus }\end{array}$ & $\begin{array}{l}\text { Candida albicans, } C . \\
\text { stellatoidea, } C . \\
\text { tropicalis, } C . \\
\text { pseudotropicalis, } C . \\
\text { krusei, Aspergillus } \\
\text { fumigatus }\end{array}$ & $\begin{array}{l}\text { Candida albicans, } C . \\
\text { stellatoidea, C. tropicalis, C. } \\
\text { pseudotropicalis, C. krusei, } \\
\text { Cryptococcus neoformans, } \\
\text { Aspergillus, Fusarium } \\
\text { oxysporum, Neurospora crassa }\end{array}$ & $\begin{array}{l}\text { C. albicans, Cryptococcus, } \\
\text { Saccharomyces, } \\
\text { Aspergillus, C. } \\
\text { neoformans, C. gattii, } \\
\text { Lomentospora } \\
\text { prolificans }\end{array}$ \\
\hline Range & $\begin{array}{l}\text { Both broad and } \\
\text { narrow ranged }\end{array}$ & Broad ranged [95] & Broad ranged [111] & Broad ranged \\
\hline Sources & $\begin{array}{l}\text { Mostly synthetic } \\
\text { preparations }\end{array}$ & $\begin{array}{l}\text { Natural plant and } \\
\text { human-based sources } \\
{[86,92]}\end{array}$ & $\begin{array}{l}\text { Natural as well as synthetic } \\
\text { preparations }\end{array}$ & $\begin{array}{l}\text { Repurposed traditional } \\
\text { drugs }\end{array}$ \\
\hline $\begin{array}{l}\text { Reported } \\
\text { cases of } \\
\text { resistance }\end{array}$ & High $[27,158]$ & Not reported yet & Not reported yet & Not reported yet \\
\hline $\begin{array}{l}\text { Feasibility of } \\
\text { therapeutics }\end{array}$ & Yes, in practice & Yes, tested $[157,87]$ & Yes, tested $[111,126]$ & Yes, tested \\
\hline
\end{tabular}

\section{INORGANIC NANOPARTICLES AS ANTIMICROBIALS}

Inorganic nanosized particles (10-15 nm dimension) have been gaining importance because of their efficiency as biocidal agents against both pathogenic bacteria and fungi [28-30].

Silver nanoparticles (AgNPs) are one of the most successful and widely used antimicrobial agents because of their multi-targeted actions on pathogens. Ag+ ions released by AgNPs interfere with electron transport and in the transduction of signals, leading to the damage of bacterial DNA, cell membranes and proteins (Fig. 3) [31, 32]. AgNPs have demonstrated antibacterial properties in vitro against ampicillin-resistant bacterial pathogens such as
E. coli, S. aureus (ATCC 25923), K. pneumoniae and $H$. influenzae $[33,34]$ and in vivo activity in a murein model against an MDR strain of $P$. aeruginosa [35]. The antifungal activity of AgNPs has also been well established, and studies by Bocate et al. and Bahrami-Teimoori et al. have demonstrated the efficacy of AgNPs against several pathogenic fungal species such as Aspergillus ochraceus, A. flavus, A. parasiticus, A. nomius, A. melleus, Fusarium oxysporum, Macrophomina phaseolina and Alternaria alternata $[36,37]$.

Zinc oxide $(\mathrm{ZnO})$ NPs have also received much attention because of their biocidal activity [30, 38]. Their applications result in cell shrinkage, disorganization and cell death, as has been confirmed by confocal laser scanning microscopy (CLSM) and scanning electron 


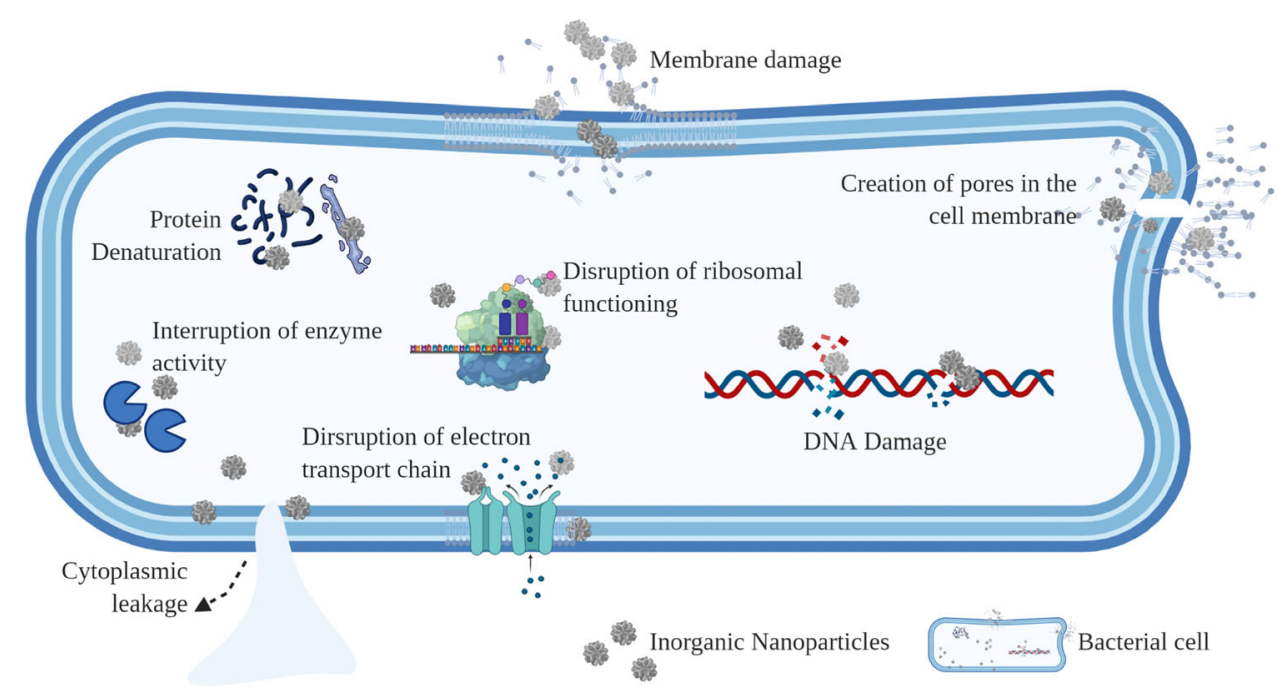

Fig. 3 Diagrammatic illustration of known antibacterial mechanisms of inorganic nanoparticles (NPs). Inorganic NPs cause membrane damage and form pores causing cytoplasmic leakage and also interruption of electron

microscopy (SEM) analysis in some reports (Fig. 3) [39, 40]. These NPs have demonstrated growth inhibition and a decrease in infectivity in K. pneumoniae and increased permeability and disintegration of the cell membrane in E. coli [41]. The antimicrobial activity of $\mathrm{ZnO}$ NPs has been demonstrated experimentally in both in vitro and in vivo set-ups. These NPs are not just bactericidal; their antifungal efficacy has also been indicated by several studies. Green synthesis procedures of $\mathrm{ZnO}$ NPs also have added advantages and shown inhibitory effects against pathogenic $C$. albicans and $A$. niger [30, 42-44].

Given the promising potential of inorganic NPs, studying their safety and efficacy and developing them as therapeutics requires more attention. Important factors to consider should be measuring their toxicity, stability and immuno-modulatory response [32].

\section{BACTERIOPHAGES AS ANTIBACTERIAL AGENTS}

Bacteriophages (phages in short) are bacterial viruses that infect bacterial hosts through highly specific interactions [45, 46]. Phages transport chain and activity of essential bacterial enzymes. Other antibacterial activities of NPs include damage to bacterial DNA and proteins, collectively leading to cell death

typically follow two different cycles: lytic and lysogenic. In the lytic cycle, phage infection is followed by lysis of the host bacterium and the release of new viral particles (Fig. 4). The lysogenic cycle involves the integration of the viral genome into the genome of the host bacteria as a prophage, which remains integrated with the host until an event triggers the release of new virions [46, 47].

Phage therapy (using lytic bacteriophages to treat bacterial infections) dates back to the early 1900s when Frederick Twort (1915) and Felix d'Hérelle (1917) discovered phages independently. Felix d'Hérelle had successfully used phages for the first time to treat dysentery, a disease that did not have an effective treatment then. In the 1920s and 1930s, phage therapy was being commonly used in several parts in Europe and the erstwhile Soviet Union. However, the advent of antibiotics eclipsed the use of phage therapy in most parts of the world except for a few countries of Eastern Europe where it is still practiced, such as the Eliava Phage Therapy Center in Tbilisi, Georgia, and the Phage Therapy Unit (PTU) of Hirszfeld Institute of Immunology and Experimental Therapy, Wrocław, Poland, among others [48]. Over the years, recommended prerequisites for 


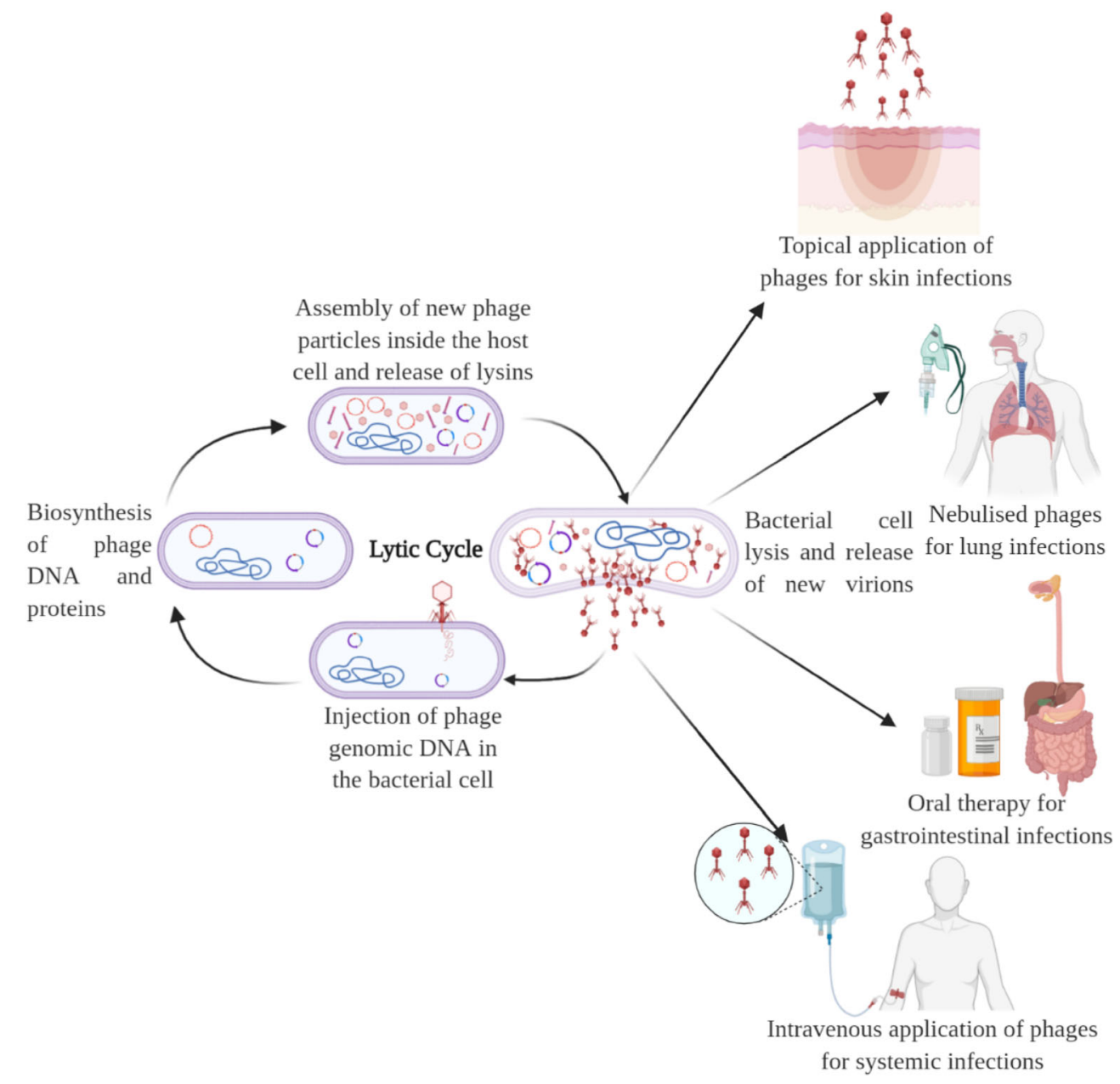

Fig. 4 Therapeutic usage of lytic bacteriophages to treat bacterial infections. The figure illustrates the lytic cycle of bacteriophages and the known methods for their administration for the treatment of bacterial infections

therapeutic application of phages have emerged which need to be adhered to, including the use of well-characterized infective phages with no or permissible levels of endotoxins [49-51]. The use of bacteriophages as investigative new drugs (IND) for treating patients who are unresponsive to available antibiotics has been approved by the FDA in several cases and is gaining wide acceptance $[52,53]$.

Recent successful cases of phage therapy in treating life-threatening infections in humans have reignited interest in phage therapy, and modern technology-fueled research is being carried out toward addressing gaps in our understanding of phage biology [54, 55]. A study by Schooley et al. describes how nine different bacteriophages were used in personalized therapy for the treatment of a 68 -year-old patient with pancreatitis accompanied by a MDR A. baumannii infection. Phages, in this case, were administered both intravenously and percutaneously within the abscess cavities, which led to clearance of the pathogen. Moreover, phage-resistant $A$. baumannii strains that developed during the therapy were found to have increased sensitivity to antibiotics, which dramatically improved the patient's condition [54]. The phage cocktails from the Eliava Institute, Tbilisi, comprise phages that infect several different species of pathogens. The pyophage preparation containing phages against $S$. aureus, Streptococcus sp., P. aeruginosa, E. coli and Proteus 
has been used for patients suffering from urinary tract and digestive system infections along with bronchopneumonia, leading to successful clearance of the pathogens. The intestiphage mixture consisting of phages against pathogenic E. coli, Shigella sp., Proteus sp., Staphylococcus sp., Pseudomonas sp. and Salmonella sp., responsible for causing intestinal problems, was successfully used in a trial comprising 580 children [56]. Apart from these reports, the Eliava Phage Therapy Center has also successfully treated many patients suffering from MDR strains of Achromobacter xylosoxidans causing lung infection in cystic fibrosis [57]. These successes indicate phages could be potential game changer when dealing with drug-resistant secondary infections in COVID-19 patients as well. Unlike antibiotics, natural phages can be rapidly isolated in large amounts. Synthetic biology can also generate innumerable variants of a phage [58]. In addition, the delivery and administration of several phages as therapeutics are well established [59]. Ryan et al. have described successful routes for phage applications including inhalation of nebulized phages for lung infections, topical applications for local delivery and oral intake for gastrointestinal infections (Fig. 4) [60]. FDA approval of phage therapy against secondary infections for patients in critical care with COVID-19 in 2020 reinforces the role bacteriophages can play in managing the pandemic [61].

\section{REPURPOSED DRUGS}

The paucity of new antibiotics and the discovery and development of new drugs inherently being a lengthy process that incurs huge costs [62], repurposing of existing drugs is gaining interest and acceptance for treating multidrugresistant (MDR) infections and other human diseases (Fig. 5). Overall, it involves lower costs and shorter development timelines [63, 64]. A review of the field shows several approved drugs have already been repurposed for new therapeutic uses [65-67]. Sildenafil, which was originally intended to treat hypertension, is being repurposed for the treatment of erectile dysfunction and pulmonary arterial hypertension.
Bupropion, thalidomide and minoxidil are also being repurposed [68]. Many of the drugs (remdesivir, hydroxychloroquine and ribavirin) used in the treatment of COVID-19 are fresh examples of repurposed drugs. Drug repurposing hence should be vigorously pursued as a promising approach for finding drugs against antibiotic-resistant secondary bacterial/fungal infections [69].

\section{Repurposed Drugs for Treating Bacterial Infections}

Ciclopirox is an off-patent topical antifungal drug that also has the potential to inhibit the growth of $A$. baumannii, $K$. pneumoniae, $P$. aeruginosa (including MDR isolates) and $P$. mirabilis. In $P$. aeruginosa ciclopirox inhibits the production of pyocyanin, a secondary metabolite, and also may decrease the production of pyoverdine, an iron-scavenging siderophore that contributes to the pathogenicity of $P$. aeruginosa [70, 71]. Statins also have been reported to reduce virulence factors of $P$. aeruginosa and in vivo attachment of $S$. pneumoniae to lung and vascular tissues and have shown broad-spectrum antibacterial effect though at relatively high concentrations [72, 73].

\section{Repurposed Drugs for Treating Fungal Infections}

For treating fungal infections (Table 4, Fig. 5), currently, the most prescribed drugs that show broad-spectrum antifungal activity are azoles, including ketoconazole, voriconazole, itraconazole, polyenes and echinocandins [74, 75]. Among the repurposed drugs, the antifungal activity of tamoxifen, a generic anticancer drug used in treating breast cancer patients, has been demonstrated by a library screening of FDAapproved drugs $[76,77]$. Interestingly, estrogenreceptor independent mechanisms of the drug have been suggested to be related to its antifungal activity. Another example is the antirheumatic drug auranofin, found to be active against C. albicans biofilms [78]. Auranofin has recently also been reported against Cryptococcus, the causative agent of cryptococcosis, which is 


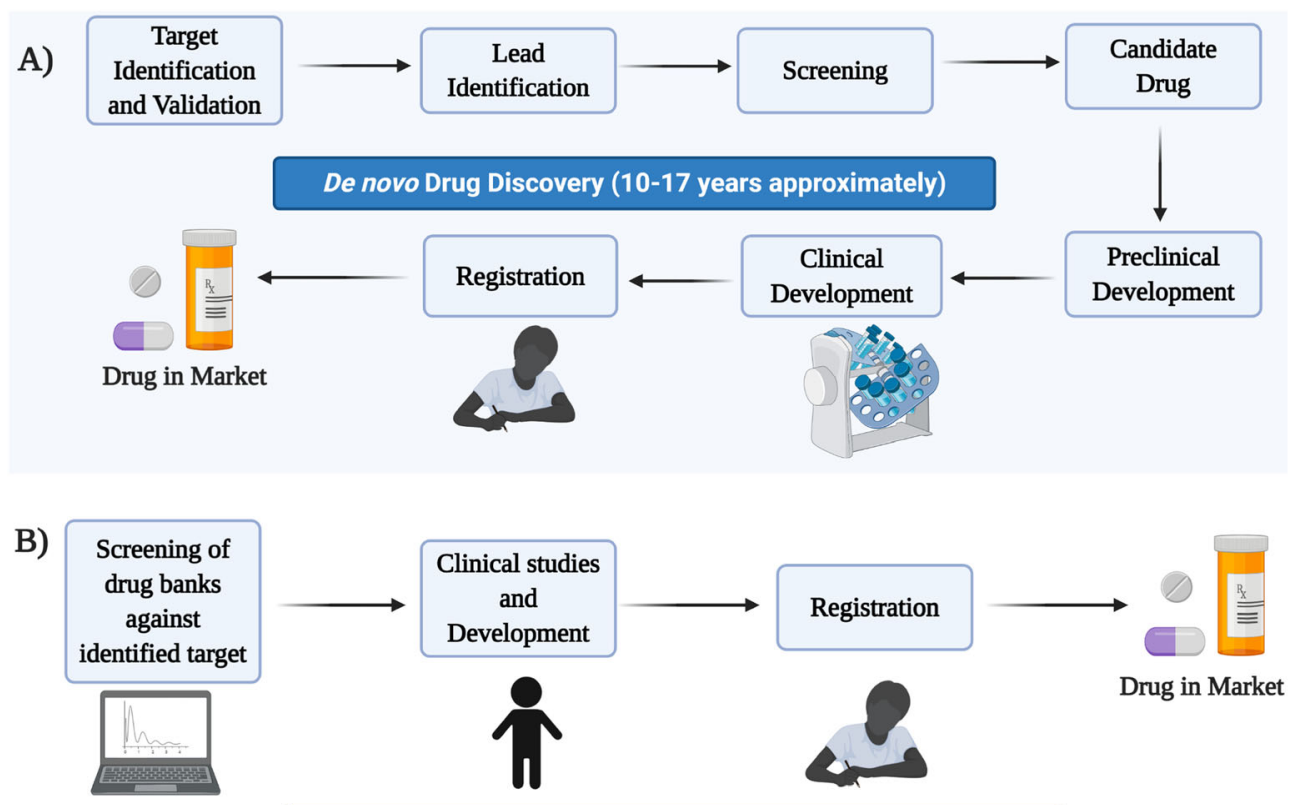

Repurposing Drugs (1-4 years approximately)

Fig. 5 Schematic representation of de novo drug discovery vs. repurposing of available drugs. De novo drug discovery and development can take up to 15 years for a drug to be available for clinical use. Drug repurposing by-passes time taken from drug discovery to pre-clinical stage

Table 4 Examples of the reported repurposed drugs against pathogenic bacteria and fungi

\begin{tabular}{|c|c|c|}
\hline Drug & Initial usage & Repurposed against \\
\hline Tamoxifen [63] & Anti-cancer drug & Staphylococcus aureus \\
\hline Diflunisal $[82]$ & $\begin{array}{l}\text { Non-steroidal anti- } \\
\text { inflammatory drug }\end{array}$ & Staphylococcus aureus (MRSA) \\
\hline Nicosalmide [159] & Antihelminthic drug & Psuedomonas aeruginosa \\
\hline Oxyclozanide [150] & Veterinary anthelmintic drug & Staphylococcus aureus \\
\hline Chlorpromazine $[160]$ & Antipsychotic drug & Klebsiella pneumoniae \\
\hline Sertraline $[160]$ & Antidepressant drug & Enterococcus faecalis \\
\hline $\begin{array}{l}\text { Nisoldipine, nifedipine, } \\
\text { felodipine }[80]\end{array}$ & Calcium channel blockers & Saccharomyces, aspergillus, cryptococcus \\
\hline $\begin{array}{l}\text { Asprin, ibuprofen, tacrolimus } \\
\text { [76] }\end{array}$ & Anti-inflammatory drug & C. neoformans, C. gattii and E. rostratum \\
\hline Atorvastatin $[81]$ & Cardiovascular drug & C. gattii \\
\hline MMV665943 [161] & Preclinical malarial drug & $\begin{array}{l}\text { C. albicans, C. neoformans, C. gattii and Lomentospora } \\
\text { prolificans }\end{array}$ \\
\hline
\end{tabular}


one of the most crucial fungal infections affecting immunocompromised patients [79]. Additionally, nifedipine, nisoldipine and felodipine also inhibit Cryptococcus, where nisoldipine has been reported to be effective against Candida, Saccharomyces and Aspergillus [80]. Several anti-inflammatory drugs such as aspirin, ibuprofen, and tacrolimus have exhibited antifungal properties against $C$. neoformans, C. gattii and E. rostratum, respectively [76]. Atorvastatin, a cardiovascular drug, has been tested as an adjuvant to control fungal infections in a study which showed the potency against one strain of C. gattii [81]. MMV665943 is a preclinical antimalarial drug that has been reported exhibiting inhibitory response against C. albicans, C. neoformans, C. gattii and Lomentospora prolificans (Table 4) [82]. An increase in the biofilm-related infections worldwide and their recalcitrant response to classical antifungal drugs call for drug repurposing as a faster and cheaper approach to treat fungal infections (Fig. 5). A seeming lack of incentives for repurposing drugs compared to those for de novo drug development is however an impediment. Incentives like patent protection and tight regulations for entry by generic pharmaceutical manufacturers can help overcome some of the hurdles [68].

\section{ENZYMES AS ANTIMICROBIAL AGENTS}

\section{Development of Antifungal Enzymes as Antimicrobial Agents}

\section{Lysozymes}

Lysozymes are antimicrobial enzymes that hydrolyze 1, 4-beta-linkages of $\mathrm{N}$-acetylmuramic acid and $\mathrm{N}$-acetyl-D-glucosamine in the bacterial cell walls, leading to cell lysis (Fig. 6). The human body synthesizes and secretes lysozymes naturally as a defense against pathogenic bacteria and fungal pathogens such as C. albicans, C. stellatoidea, C. tropicalis, C. pseudotropicalis and others [83, 84]. Five antimicrobial peptides obtained on pepsin digestion of lysozyme have been found to be effective against $C$. albicans [85]. Lysozymes from different sources, such as Phaseolus mungo and Galleria mellonella, have also been demonstrated to have antifungal potential and therefore could be potent sources for lysozymes for therapeutic purposes [84].

\section{Chitotriosidase}

When activated, macrophages and neutrophils in humans release the chitotriosidase enzyme, which is known to cleave chitin and kill invasive mycoses (Fig. 6) [86, 87]. High concentrations of chitotriosidase enzyme are expressed in the human eye, especially in the lacrimal glands, for defense against fungal organisms [88]. Chitotriosidase is currently used as a biomarker of macrophage activation caused by diseases such as sarcoidosis and various lipid storage diseases including Gaucher disease (GD) $[89,90]$. Increased expression of chitotriosidase mRNA has been observed in animal models, suggesting them to be important mediators in immune responses [91].

\section{Lactoferrins}

Lactoferrins are proteases that bind to iron atoms and are omnipresent in almost all secretions of the body, including the salivary secretions. Lactoferrins produced by humans are found to be effective against $C$. krusei and $C$. albicans [92, 93]. Acceptable sources of bovine and recombinant human lactoferrins are accessible for commercial applications, although further research is required for its medicinal use [94]. Their microbial activity has been shown to be very broad in nature due to their ability to sequester ferric ions [95, 96]. Some clinical studies showed that oral administration of bovine lactoferrins can significantly reduce an already established candidiasis in mice. The therapeutic effect of orally administered lactoferrins also has exhibited a reduction in lesions in the oral cavity [97].

\section{Antileukoproteases (ALP)}

Antileukoproteases are serine-based mucous protease inhibitors and can be traced in bodily secretions of bronchial, cervical and nasal mucosa along with saliva and seminal fluids. The antifungal effect of recombinant ALP against $A$. fumigatus and $C$. albicans has been 


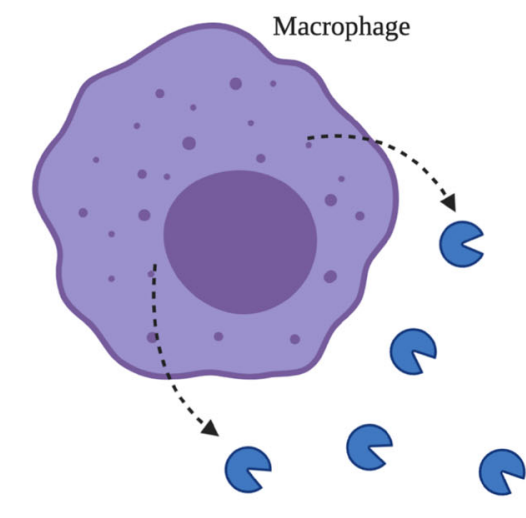

Secretion of Lysozyme and Chitotriosidase by human / mammalian macrophages.
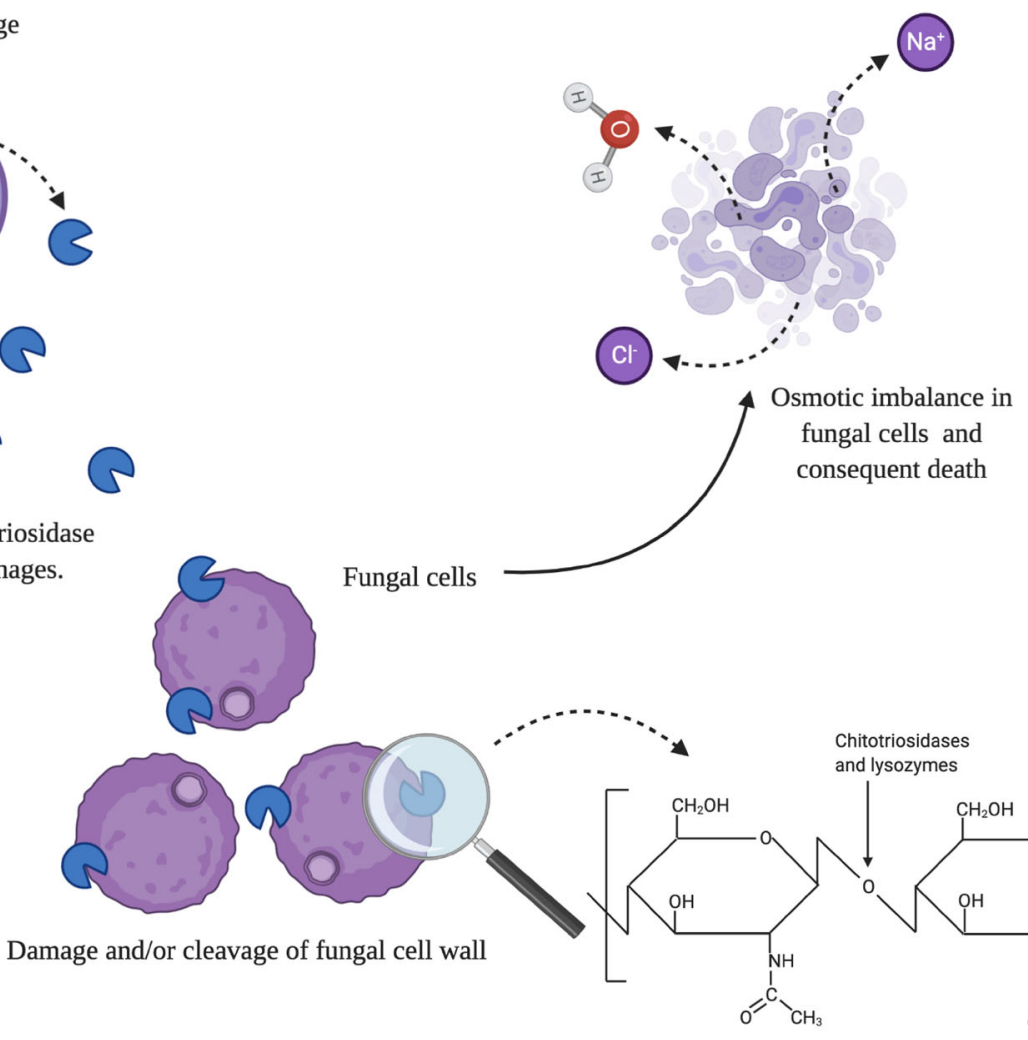

Fig. 6 Antifungal action of macrophage-secreted lysozyme and chitotriosidases. Various antifungal enzymes are secreted by the macrophages, for instance, the chitotriosidase cleaves the fungal cell wall and causes the rupture of

studied by Tomee et al. [98]. ALPs have been recommended as an alternative approach to traditional antifungal therapies and have also been suggested as a mode of treatment of fungal infections in immunocompromised patients and thus can play a key role in the management of secondary infections in COVID-19 patients $[87,98]$.

\section{PHAGE LYSINS (ENZYBIOTICS)}

The vast collection of whole-genome sequences of phages and characterization of their proteome have emerged as a blueprint from which several novel antibacterial agents can be developed. The bacteriophage-encoded lytic enzymes (lysins) are fast emerging $[99,100]$ as potential antibacterial agents due to their efficiency in cleaving the bacterial cell wall (Fig. 7). An cells. Other enzymes such as lysozymes, which may be secreted by both neutrophils and macrophages, are said to damage the fungal cell wall, thereby causing an osmotic imbalance leading to cell death

increase in the number of new phage genomes/ metagenomes in the database reveals the discovery of many novel lysin sequences. Compared to broad-spectrum, standard-of-care antibiotics, lysins are highly specific and do not cause harm to the healthy commensal microflora. They can be effective against both drugsensitive and drug-resistant strains of pathogens and against dividing as well as non-dividing bacterial cells [100, 101]. Since peptidoglycan (PG) is the key integral component of the bacterial cell wall, the probability of bacteria modifying PG to thwart lysin attack is considerably low. Due to an efficient mechanism of action and their prospective use as the nextgeneration antimicrobials, phage lysins have been termed 'enzybiotics' [102].

On a promising note, lysins have exhibited a substantial response in human trials. A single dose of exebacase, an anti-staphylococcal lysin, 

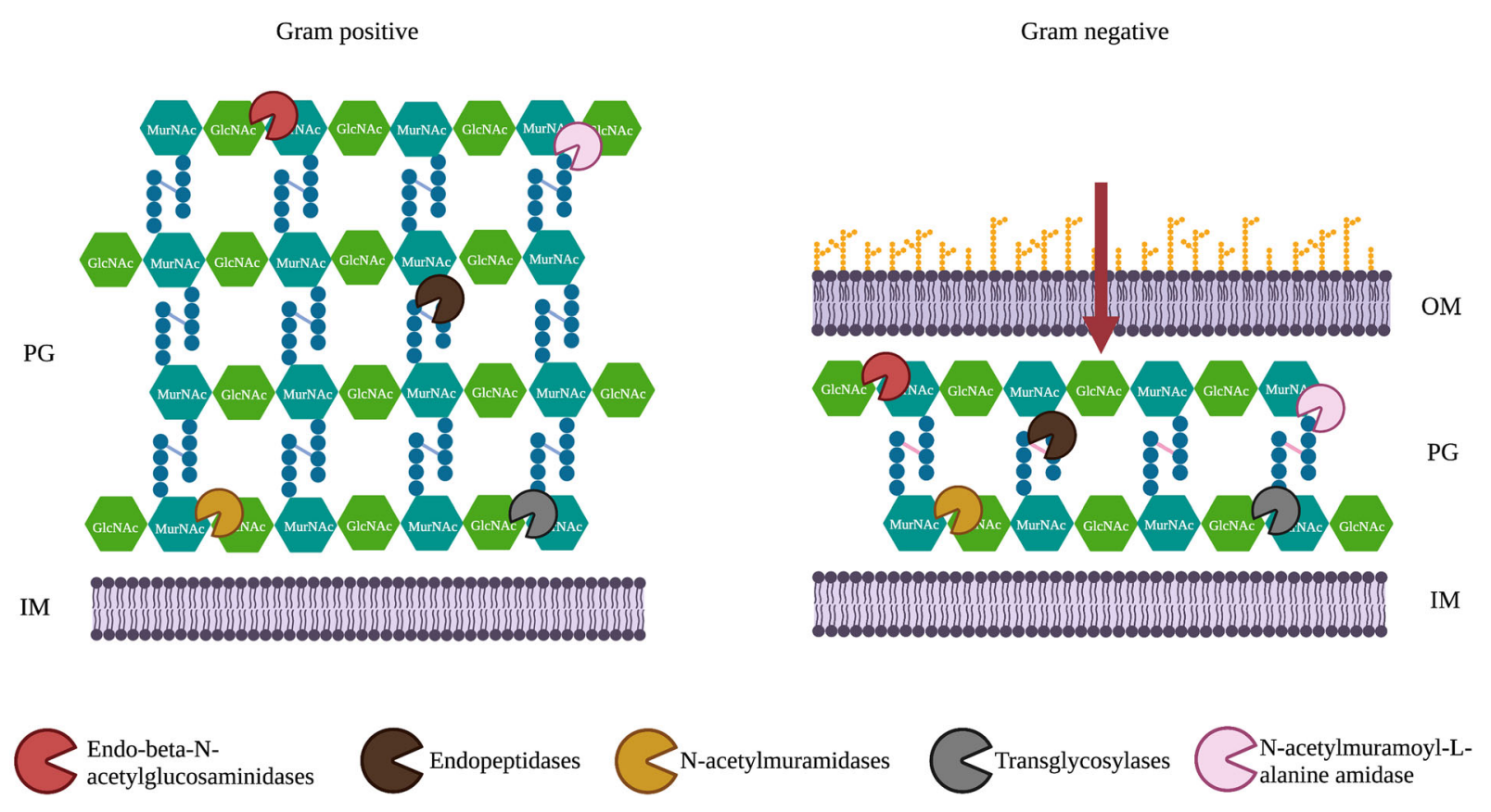

Fig. 7 Pictorial depiction of endolysin activity on the peptidoglycan layer (PG) of bacterial cells. PG layer here is represented by the repeating units of sugars $N$-acetylglucosamine (GlucNAc) and $N$-acetylmuramic acid (MurNAc). For gram-negative bacteria, endolysins (cleavage site represented as Pacman) have to transverse (red arrow) the

showed a $70.4 \%$ responder rate when used in combination with antibiotics on patients suffering from bacterial endocarditis during its phase 2 clinical trial [103]. Lysins have also been developed for commercial applications. These include Staphefekt ${ }^{\mathrm{TM}}$ SA.100, which is available as a gel or cream, and Staphefekt ${ }^{\mathrm{TM}}$ XDR.300 (Gladskin), available as an aseptic solution. Both products specifically target MRSA infection of the skin (http://www.micreos.com/) [100]. Preclinical and early phase clinical trials have demonstrated the lytic efficiency of phage lysins. P128, a chimeric ectolysin, was demonstrated to have rapid antibacterial efficacy in vivo against MRSA and VRSA infections in a murine model [104]. Another study demonstrated the potency of a pneumococcal lysin against drug-resistant $S$. pneumoniae, the pathogen responsible for causing pneumonia, bronchitis and septicemia. Intravenous injection of lysin Cpl-1 (2 mg) in mouse models demonstrated reduction of the bacterial load outer membrane (OM). PG in gram-positive bacteria consists of tetrapeptide chains (blue spheres), which are cross-linked by interpeptide bridges (blue line), while in gram-negative bacteria tetrapeptide bridges are cross-linked by pentapeptide bridges (pink line). IM represents the inner membrane

from 4 logs to undetectable levels $(\sim<2$ logs $)$ within 15 min of application, resulting in faster recovery from fatal pneumonia compared to the control group [105]. Another lysin (Pal) has given positive results against $S$. pneumoniae infection of the murine nasopharynx by eliminating the pathogen using a single dose with no post-treatment recolonization [101].

Secondary pneumococcal infections which are resistant to available antibiotics are a matter of great concern in COVID-19-infected patients. As antibiotics fail to meet the need for an urgent solution in treating drug-resistant infections, the bacteriolytic activity of lysins accompanied by an antibiotic synergistic effect should be explored further to realize their potential.

\section{ANTIMICROBIAL PEPTIDES}

Antimicrobial peptides (AMPs) have powerful antibacterial, antifungal and antiviral properties 
[106]. Being produced by all organisms, natural and synthetic AMPs present a valuable source to treat infections. Their high effectiveness at inactivating pathogens with sometimes concurrent immunomodulatory effects makes AMPs promising candidate compounds for the treatment of infections. While many of the peptides kill bacteria by traversing the bacterial envelope to bind to intracellular targets, most of them insert into the membranes of the pathogen, creating perturbations and holes that lead to a collapse of the proton motive force and/or cause leakage of the cytoplasmic content [107-110]. In addition to AMPs that act against bacteria, many antifungal peptides have been discovered with both antimicrobial and immunomodulatory activities. Many of these peptides are also released by the human body as a natural defense against microbial infections and invasive mycoses. Peptides such as cathelicidin provide resistance against a broad range of infections [111]. A promising peptide, Jelleine1 , has been proven to exhibit very potent in vitro as well as in vivo antifungal activity [112]. A growing body of evidence remarkably hints at the antifungal potential of various antimicrobial peptides.

\section{Defensins}

Defensins are a group of short, positively charged peptides with cysteine residues that can be categorized based on the alignment of their disulfide bridges. Humans are known to express $\alpha$ - and $\beta$-defensins [113]. Although defensins are not restricted to humans and have also been found in a wide spectrum of organisms, ranging from simpler eukaryotes like Pseudoplectania nigrella to prokaryotes like Anaeromyxobacter dehalogenans, suggesting that the organisms evolved these mechanisms for protection against invasive mycoses in a hostile environment [114-116]. Researchers have also observed the anticandidal activity of human defensins along with the MFC (minimal fungicidal concentration) required to have an appropriate inhibitory effect in which, out of the three human defensins incorporated into the study, named human $\beta$-defensins $1-3$, defensin-3 showed the strongest fungicidal activity against C. albicans with a low MFC of $2.5 \mu \mathrm{M}$ [117]. Defensins sourced from plants and insects have also been successful in acting against pathogens that infect humans. Plant defensin 'HsAFP1' and insect-sourced defensin 'Heliomicin' both, for instance, have been very successful in eliminating colonies formed by C. albicans [118].

\section{Cathelicidins}

Cathelicidins are polypeptides that are stored in considerable concentrations in macrophages and polymorphonuclear leukocytes in humans and other animals. Their primary action is to provide an antimicrobial defense barrier for the skin and exposed surfaces of the body that are vulnerable to infection and invasion. They have a conserved 'cathelin' domain and a positively charged peptide at the C-terminal that confers an antimicrobial property to these molecules [111]. They are generally synthesized and secreted by mucosal epithelial and mast cells and are possible candidates for the treatment of fungal infections [119]. Culture-dependent antifungal activity has been shown by cathelicidins in both humans and mice; the human cathelicidin, 'LL-37', and the mouse cathelicidin, 'mCRAMP', not only impeded the growth of $C$. albicans but also eliminated it successfully in both the organisms [120]. In another study, five different cathelicidins showed significant activity in vitro against clinically isolated yeasts and C. neoformans in particular [121].

\section{Dermicidins}

Dermicidins are synthesized and produced by human sweat glands and are then transported to the skin surface. These peptides are processed before they gain antimicrobial activity. Dermicidins have been shown to possess high antifungal activity against $C$. albicans in laboratory conditions that were recreated to mimic the environment of human sweat [122]. 


\section{hGAPDH (2-32)}

A peptide that has been derived from a conserved protein, GAPDH, has been shown to confer some degree of protection to tissues against fungal infections. The hGAPDH peptide, a human GAPDH, has been shown to cause inhibition of growth of $C$. albicans in small concentrations along with simultaneous inhibition of candidal virulence factors [123].

\section{Synthetic Peptides}

Antifungal activity against $C$. albicans has been demonstrated for three chemically synthesized peptides, aurein 1.2, citropin $1.1 \mathrm{~A}$ and uperin 3.6, in a study by Kamysz et al. [124]. Especially in the case of secondary infections, where eliminating a resistant fungal infection could be challenging, peptides like VS2 and VS3 in combination with fluconazole were observed to have a significant impact on decelerating the growth of multidrug-resistant Candida spp., Cryptococcus neoformans, Aspergillus. niger, Fusarium oxysporum and Neurospora crassa. These peptides were also seen to induce necrosis by causing intracellular accumulation of reactive oxygen species (ROS) and exhibited rapid activity on the killing kinetics assay [125]. Other synthetic peptides such as KSL-W also demonstrated potent antifungal activity [126].

\section{Next-Generation Antibiotics and Antifungal Agents}

It is evident from the COVID-19 pandemic that the secondary infections caused by bacterial and fungal pathogens are a significant threat, especially to immunocompromised patients. Considering the increasing rise in antibiotic resistance, our focus on developing effective strategies based on several alternatives to manage infections is timely. It is also important here to highlight the drug discovery program underway toward developing the next generation of antimicrobials.

\section{Small Molecule Inhibitors as Antibacterial Agents}

Small chemical compounds that can target a variety of cellular loci, ranging from the cytoplasmic membrane, enzymes to respiratory functions and genetic material are good starting points in the drug discovery and development process [127]. There are novel classes of molecules that are providing new ways to assist the development of antimicrobial therapies [128]. In particular, we discuss the novel targets in pathogenic bacteria in the early stages of development (Fig. 8).

One such class of inhibitors that have an added advantage of selectivity over other antimicrobials are those which target DNA repair mechanisms as the molecular targets. Lim et al. discovered a compound, IMP-1700, that not only inhibited DNA repair in MRSA but was also found to sensitize bacteria to fluoroquinolone antibiotic ciprofloxacin, which is responsible for the induction of DNA damage [129]. Another compound, POL7080, has been demonstrated as an inhibitor of LptD, a protein involved in lipopolysaccharide insertion in the outer membrane of $P$. aeruginosa. LptD has low mutation rates and is well conserved across many bacterial species $[129,130]$.

IgA protease in $H$. influenzae is a virulence factor secreted by various gram-negative bacteria and is a promising target for new drugs for managing antibiotic-resistant $H$. influenzae strains [131]. Apart from targeting essential and unique enzymes in pathogens, structural variations in a host enzyme and pathogen enzyme are another aspect to limit microbial infection. Pseudouridimycin is one such recently reported inhibitor that binds selectively to bacterial RNA polymerase and is assumed to be efficacious against a variety of drug-resistant pathogens [132]. Nucleoside analogues often used to treat viral and fungal infections are also promising candidates for treating bacterial infections [133]. 


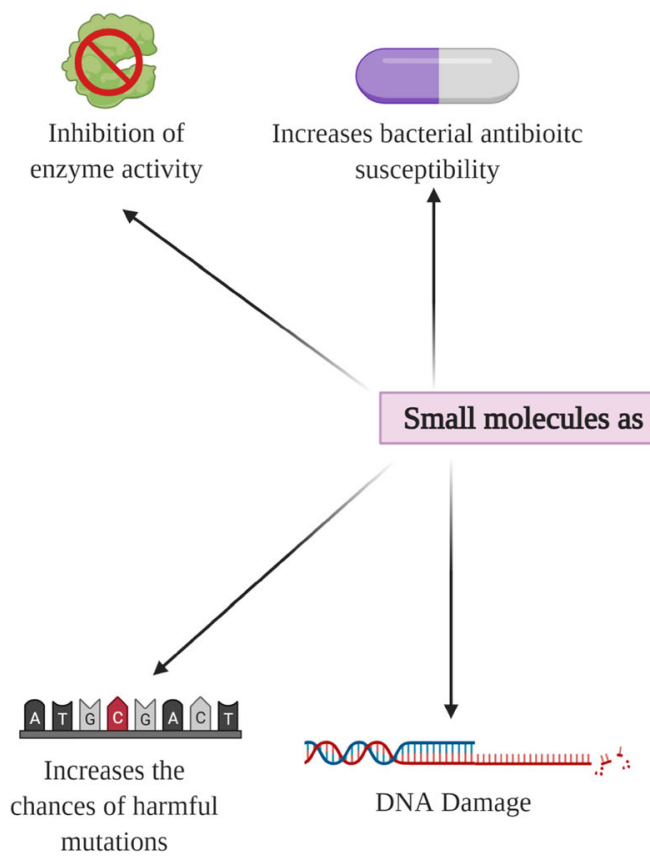

Fig. 8 Molecular antibacterial mechanisms of small molecules. Small molecules are known to inhibit bacterial DNA repair mechanisms and enhance bacterial susceptibility to the antibiotic ciprofloxacin, which further induces DNA damage. Also, several other small molecules

\section{Small Molecule Inhibitors as Antifungal Agents}

The discovery of novel bioactive antifungal compounds and the identification of molecular targets are of extreme importance [134]. SARSCoV-2 patients being immunocompromised have higher chances to suffer from invasive fungal infections causing aspergillosis (Aspergillus infection), candidiasis (Candida infection), cryptococcosis (Cryptococcus infection) and mucormycosis (Mucorales infection) [22].

Tertiary RNA structures are emerging as effective de novo targets that can lead to the discovery of pharmacologically active and nontoxic antifungal molecules. RNA structures such as self-splicing group-II intron are found in eukaryotes such as plants, yeast and fungi and are absent in human cells. These compounds are effective and comparable to amphotericin B in inhibiting the growth of C. parapsilosis [135].

A dominant virulence attribute of fungi such as C. albicans is yeast to hyphae transition,
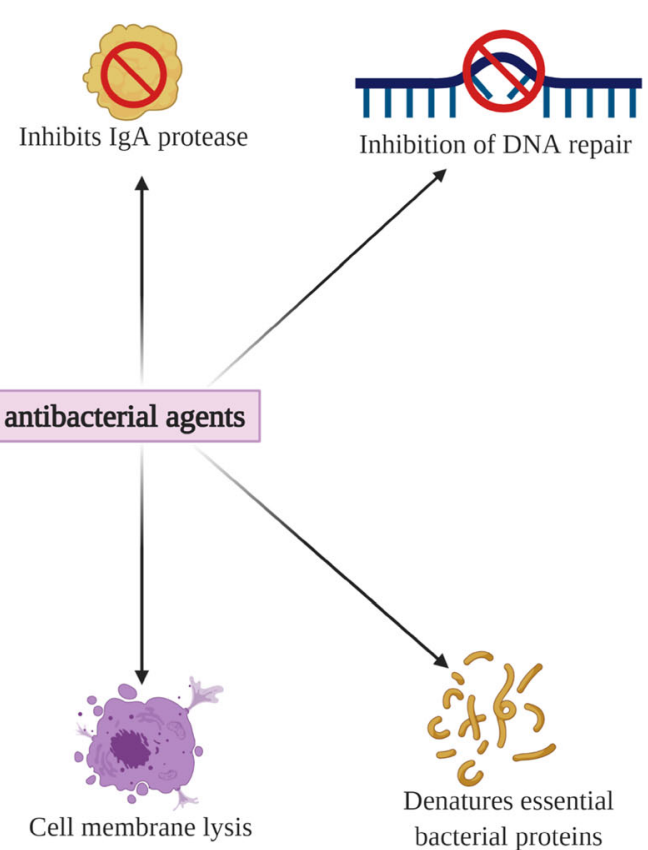

(example: IMP-1700) are found to be efficacious against pathogens by inhibiting and denaturing the activity of certain essential enzymes required for the survival of the bacteria

which is another promising drug target. In a study on the discovery of small molecule inhibitors against Candida infections by Wong et al., screening a library of 50,240 compounds led to the discovery of a novel compound called SM21, which exhibits strong activity against drug-resistant Candida isolates and biofilm. SM21 was also found to be non-toxic to human cells (Fig. 9) [136].

In addition to similar studies, several small molecules such as farnesol, rapamycin, geldanamycin, histone deacetylase inhibitors and cell cycle inhibitors in C. albicans that control hyphae production have been reported [137].

\section{CONCLUSION}

Secondary infections are the major cause of death in immunocompromised SARS-CoV-2infected patients. There is an urgent need to review the current drug regime and fast-track research and pre-clinical/clinical studies 


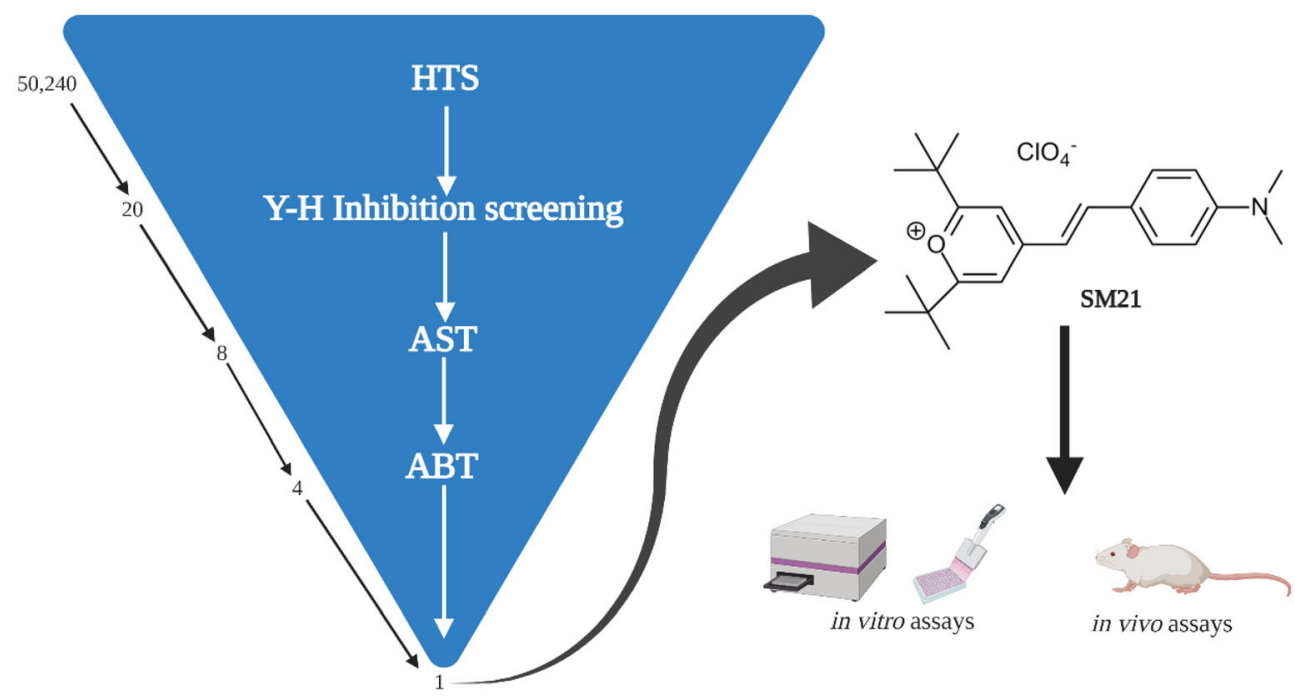

Fig. 9 Screening of novel antifungal small molecules. Wong et al.'s study is a potent example of how novel antifungal molecules are screened from a library of molecules. High-throughput screening (HTS) of a library of 50,240 small molecules was done for Y-H inhibitors, which yielded 20 active compounds that were further validated by assessing their activity in a dose-dependent

required for the development of credible alternatives to treat primary or secondary drug-resistant infections. This pandemic impels us to explore therapeutic options beyond the conventional and tap into less studied methods of treatment. Several promising developments in the field of antimicrobials have been made lately, as traced in this review, and we believe a multipronged approach can be a better way to deal with secondary infections instead of depending on antibiotics alone. However, validation of the merits, safety and efficacy of these strategies through clinical trials needs to be expedited. Entailing mechanisms for compassionate use of the suggested treatments need to be brought into mainstream discussion as well. Preparedness for future global crises such as the current coronavirus pandemic is imperative.

\section{ACKNOWLEDGEMENTS}

All figures were created using BioRender.com (https://biorender.com). Acharya Narendra Dev manner. Eight molecules were identified as potent $\mathrm{Y}-\mathrm{H}$ inhibitors, which were further analyzed in an antifungal susceptibility test (AST). The four most potent molecules were selected for an anti-biofilm test (ABT), which led to SM21, the most potent of all, that was chosen for further in vitro and in vivo assays

College (ANDC), University of Delhi is gratefully acknowledged for providing infrastructural facilities.

Funding. The authors gratefully acknowledge the grant (SERB PROJECT EMR/2017/ 004051) support from Department of Science \& Technology (DST), Govt of India in the preparation of the review article.

Authorship. All named authors meet the International Committee of Medical Journal Editors (ICMJE) criteria for authorship for this article, take responsibility for the integrity of the work, and have given their approval for this version to be published.

Author Contributions. Conceptualization, Ritam Das; investigation, Ritam Das, Komal Kotra, Pulkit Singh, and Urmi Bajpai; writingoriginal draft preparation, Ritam Das, Komal Kotra, Pulkit Singh; writing_-review and editing Urmi Bajpai, Belinda Loh and Sebastian Leptihn; supervision, Urmi Bajpai and Sebastian 
Leptihn All authors have read and agreed to the published version of the manuscript.

Disclosures. Ritam Das, Komal Kotra, Pulkit Singh, Belinda Loh, Sebastian Leptihn and Urmi Bajpai confirm that they have nothing to disclose. The authors declare no conflict of interest.

Compliance with Ethics Guidelines. This article is based on previously conducted studies and does not contain any new studies with human participants or animals performed by any of the authors.

Data Availability. Data sharing is not applicable to this article as no datasets were generated or analyzed during the current study.

Open Access. This article is licensed under a Creative Commons Attribution-NonCommercial 4.0 International License, which permits any non-commercial use, sharing, adaptation, distribution and reproduction in any medium or format, as long as you give appropriate credit to the original author(s) and the source, provide a link to the Creative Commons licence, and indicate if changes were made. The images or other third party material in this article are included in the article's Creative Commons licence, unless indicated otherwise in a credit line to the material. If material is not included in the article's Creative Commons licence and your intended use is not permitted by statutory regulation or exceeds the permitted use, you will need to obtain permission directly from the copyright holder. To view a copy of this licence, visit http:// creativecommons.org/licenses/by-nc/4.0/.

\section{REFERENCES}

1. Manohar P, Loh B, Nachimuthu R, Hua X, Welburn SC, Leptihn S. Secondary bacterial infections in patients with viral pneumonia. Front Med. 2020;7: 420.

2. Mirzaei R, Goodarzi P, Asadi M, Soltani A, Aljanabi HAA, Jeda AS, et al. Bacterial co-infections with SARS-CoV-2. IUBMB Life. 2020;72(10):2097-111.
3. Manohar P, Loh B, Leptihn S. Will the overuse of antibiotics during the Coronavirus pandemic accelerate antimicrobial resistance of bacteria? Infect Microbe Dis. 2020;2:87-8.

4. Fu Y, Yang Q, Xu M, Kong H, Chen H, Fu Y, et al. Secondary bacterial infections in critical ill patients of COVID-19. Open Forum Infect Dis. 2020;7:220.

5. Udwadia ZF, Tripathi AR, Nanda VJ, Joshi SR. Prognostic factors for adverse outcomes in COVID19 infection. J Assoc Physicians India. 2020;68(7): 56-60.

6. Yang X, Yu Y, Xu J, Shu H, Liu H, Wu Y, et al. Clinical course and outcomes of critically ill patients with SARS-CoV-2 pneumonia in Wuhan, China: a single-centered, retrospective, observational study. Lancet Respir Med. 2020;8:475-81.

7. Chen T, Wu D, Chen H, Yan W, Yang D, Chen G, et al. Clinical characteristics of 113 deceased patients with coronavirus disease 2019: retrospective study. BMJ. 2020;368: m1295.

8. Langford BJ, So M, Raybardhan S, et al. Bacterial coinfection and secondary infection in patients with COVID-19: a living rapid review and meta-analysis. Clin Microbiol Infect. 2020;26(12):1622-9. https:// doi.org/10.1016/j.cmi.2020.07.016.

9. Zheng ZG, Chen RC, Li YM. The clinical characteristics of secondary infections of lower respiratory tract in severe acute respiratory syndrome. Chin J Respir Crit Care Med. 2003;2:270-4.

10. Sharifipour E, Shams S, Esmkhani M, Khodadadi J, Fotouhi-Ardakani R, Koohpaei A, et al. Evaluation of bacterial co-infections of the respiratory tract in COVID-19 patients admitted to ICU. BMC Infect Dis. 2020;20(1):1-7.

11. Yam ELY. COVID-19 will further exacerbate global antimicrobial resistance. J Travel Med. 2020;27: taaa098.

12. Cox MJ, Loman N, Bogaert D, O'grady J. Co-infections: potentially lethal and unexplored in COVID19. Lancet Microbe. 2020;1(1): e1.

13. Getahun H, Smith I, Trivedi K, Paulin S, Balkhy HH. Tackling antimicrobial resistance in the COVID-19 pandemic. Bull World Health Organ. 2020;98(7): 442.

14. Blair JM, Webber MA, Baylay AJ, Ogbolu DO, Piddock LJ. Molecular mechanisms of antibiotic resistance. Nat Rev Microbiol. 2015;13(1):42-51.

15. Loh B, Chen J, Manohar P, Yu Y, Hua X, Leptihn S. A biological inventory of prophages in $A$. baumannii genomes reveal distinct distributions in classes, 
length, and genomic positions. Front Microbiol. 2020;11: 579802 .

16. Leptihn S. Welcome back to the Pre-Penicillin Era. Why we desperately need new strategies in the battle against bacterial pathogens. Infect Microbes Dis. 2019;1(2):33.

17. Spellberg B, Guidos R, Gilbert D, Bradley J, Boucher HW, Scheld WM, et al. The epidemic of antibioticresistant infections: a call to action for the medical community from the Infectious Diseases Society of America. Clin Infect Dis. 2008;46(2):155-64.

18. Ventola CL. The antibiotic resistance crisis: part 1 : causes and threats. Pharm Ther. 2015;40(4):277.

19. Castanheira M, Deshpande LM, Mendes RE, Canton $\mathrm{R}$, Sader HS, Jones RN. Variations in the occurrence of resistance phenotypes and carbapenemase genes among Enterobacteriaceae isolates in 20 years of the SENTRY antimicrobial surveillance program. Open Forum Infect Dis. 2019;6(Suppl 1):S23-33.

20. Cantón R, Gijón D, Ruiz-Garbajosa P. Antimicrobial resistance in ICUs: an update in the light of the COVID-19 pandemic. Curr Opin Crit Care. 2020;26(5):433-41.

21. Brown GD, Denning DW, Gow NA, Levitz SM, Netea MG, White TC. Hidden killers: human fungal infections. Sci Transl Med. 2012;4(165): 165rv13.

22. Song G, Liang G, Liu W. Fungal co-infections associated with global COVID-19 pandemic: a clinical and diagnostic perspective from China. Mycopathologia. 2020;185:599-606.

23. Zhou F, Yu T, Du R, Fan G, Liu Y, Liu Z, et al. Clinical course and risk factors for mortality of adult inpatients with COVID-19 in Wuhan, China: a retrospective cohort study. Lancet. 2020;395:1054-62.

24. Verweij PE, Snelders E, Kema GH, Mellado E, Melchers WJ. Azole resistance in Aspergillus fumigatus: a side-effect of environmental fungicide use? Lancet Infect Dis. 2009;9(12):789-95.

25. van Arkel AL, Rijpstra TA, Belderbos HN, Van Wijngaarden P, Verweij PE, Bentvelsen RG. COVID19-associated pulmonary aspergillosis. Am J Respir Crit Care Med. 2020;202(1):132-5.

26. Chowdhary A, Tarai B, Singh A, Sharma A. Multidrug-resistant Candida auris infections in critically ill coronavirus disease patients, India, April-July 2020. Emerg Infect Dis. 2020;26(11):2694-6. https://doi.org/10.3201/eid2611.203504.

27. Denning DW, Park S, Lass-Florl C, Fraczek MG, Kirwan M, Gore R, et al. High-frequency triazole resistance found in nonculturable Aspergillus fumigatus from lungs of patients with chronic fungal disease. Clin Infect Dis. 2011;52(9):1123-9.

28. Azam A, Ahmed AS, Oves M, Khan MS, Habib SS, Memic A. Antimicrobial activity of metal oxide nanoparticles against Gram-positive and Gramnegative bacteria: a comparative study. Int J Nanomed. 2012;7:6003.

29. Gabrielyan L, Hakobyan L, Hovhannisyan A, Trchounian A. Effects of iron oxide $\left(\mathrm{Fe}_{3} \mathrm{O}_{4}\right)$ nanoparticles on Escherichia coli antibiotic-resistant strains. J Appl Microbiol. 2019;126(4):1108-16.

30. Pillai AM, Sivasankarapillai VS, Rahdar A, Joseph J, Sadeghfar F, Rajesh K, Kyzas GZ. Green synthesis and characterization of zinc oxide nanoparticles with antibacterial and antifungal activity. J Mol Struct. 2020;1211: 128107.

31. Slavin YN, Asnis J, Häfeli UO, Bach H. Metal nanoparticles: understanding the mechanisms behind antibacterial activity. J Nanobiotechnol. 2017;15(1):1-20.

32. Mulani MS, Kamble EE, Kumkar SN, Tawre MS, Pardesi KR. Emerging strategies to combat ESKAPE pathogens in the era of antimicrobial resistance: a review. Front Microbiol. 2019;10:539.

33. Hamida RS, Ali MA, Goda DA, Khalil MI, Redhwan A. Cytotoxic effect of green silver nanoparticles against ampicillin-resistant Klebsiella pneumoniae. RSC Adv. 2020;10(36):21136-46.

34. Ajah HA, Khalaf KJ, Hassan AS, Aja HA. Extracellular biosynthesis of silver nanoparticles by Haemophilus influenzae and their antimicrobial activity. J Pharm Sci Res. 2018;10(1):175-9.

35. Escárcega-González CE, Garza-Cervantes JA, Vazquez-Rodríguez A, Montelongo-Peralta LZ, TreviñoGonzalez MT, Castro EDB, et al. In vivo antimicrobial activity of silver nanoparticles produced via a green chemistry synthesis using Acacia rigidula as a reducing and capping agent. Int J Nanomed. 2018;13:2349.

36. Bocate KP, Reis GF, de Souza PC, Junior AGO, Durán $\mathrm{N}$, Nakazato G, et al. Antifungal activity of silver nanoparticles and simvastatin against toxigenic species of Aspergillus. Int J Food Microbiol. 2019;291:79-86.

37. Bahrami-Teimoori B, Nikparast Y, Hojatianfar M, Akhlaghi M, Ghorbani R, Pourianfar HR. Characterisation and antifungal activity of silver nanoparticles biologically synthesised by Amaranthus retroflexus leaf extract. J Exp Nanosci. 2017;12(1):129-39. 
38. Liu YJ, He LL, Mustapha A, Li H, Hu ZQ, Lin MS. Antibacterial activities of zinc oxide nanoparticles against Escherichia coli O157:H7. J Appl Microbiol. 2009;107(4):1193-201.

39. Hameed ASH, Karthikeyan C, Ahamed AP, Thajuddin N, Alharbi NS, Alharbi SA, Ravi G. In vitro antibacterial activity of $\mathrm{ZnO}$ and $\mathrm{Nd}$ doped $\mathrm{ZnO}$ nanoparticles against ESBL producing Escherichia coli and Klebsiella pneumoniae. Sci Rep. 2016;6(1): $1-11$.

40. Al-Sharqi A, Apun K, Vincent M, Kanakaraju D, Bilung LM. Enhancement of the antibacterial efficiency of silver nanoparticles against gram-positive and gram-negative bacteria using blue laser light. Int J Photoenergy. 2019. https://doi.org/10.1155/ 2019/2528490.

41. Reddy LS, Nisha MM, Joice M, Shilpa PN. Antimicrobial activity of zinc oxide ( $\mathrm{ZnO}$ ) nanoparticle against Klebsiella pneumoniae. Pharm Biol. 2014;52(11):1388-97.

42. Jin SE, Jin HE. Antimicrobial activity of zinc oxide nano/microparticles and their combinations against pathogenic microorganisms for biomedical applications: from physicochemical characteristics to pharmacological aspects. Nanomaterials. 2021;11(2):263.

43. Chaudhary A, Kumar N, Kumar R, Salar RK. Antimicrobial activity of zinc oxide nanoparticles synthesized from Aloe vera peel extract. SN Appl Sci. 2019;1(1):136.

44. Miri A, Mahdinejad N, Ebrahimy O, Khatami M, Sarani M. Zinc oxide nanoparticles: biosynthesis, characterization, antifungal and cytotoxic activity. Mater Sci Eng C. 2019;104: 109981.

45. Duckworth DH, Gulig PA. Bacteriophages. BioDrugs. 2002;16(1):57-62.

46. Domingo-Calap P, Delgado-Martínez J. Bacteriophages: protagonists of a post-antibiotic era. Antibiotics. 2018;7(3):66.

47. Maurice CF, Bouvier CD, De Wit R, Bouvier T. Linking the lytic and lysogenic bacteriophage cycles to environmental conditions, host physiology and their variability in coastal lagoons. Environ Microbiol. 2013;15(9):2463-75.

48. Chan BK, Abedon ST, Loc-Carrillo C. Phage cocktails and the future of phage therapy. Future Microbiol. 2013;8(6):769-83.

49. Levin BR, Bull JJ. Population and evolutionary dynamics of phage therapy. Nat Rev Microbiol. 2004;2(2):166-73.
50. Skurnik M, Strauch E. Phage therapy: facts and fiction. Int J Med Microbiol. 2006;296(1):5-14.

51. Cui Z, Guo X, Feng T, Li L. Exploring the whole standard operating procedure for phage therapy in clinical practice. J Transl Med. 2019;17(1):1-7.

52. McCallin S, Sacher JC, Zheng J, Chan BK. Current state of compassionate phage therapy. Viruses. $2019 ; 11(4): 343$.

53. Sacher JC, Zheng J. Phage therapy collaboration and compassionate use. Bacteriophages: biology, technology, therapy, p. 1069-98 (2021).

54. Schooley RT, Biswas B, Gill JJ, Hernandez-Morales A, Lancaster J, Lessor L, et al. Development and use of personalized bacteriophage-based therapeutic cocktails to treat a patient with a disseminated resistant Acinetobacter baumannii infection. Antimicrob Agents Chemother. 2017;61(10): e00954-17.

55. Dedrick RM, Guerrero-Bustamante CA, Garlena RA, Russell DA, Ford K, Harris K, et al. Engineered bacteriophages for treatment of a patient with a disseminated drug-resistant Mycobacterium abscessus. Nat Med. 2019;25(5):730-3.

56. Kutateladze Á, Adamia R. Phage therapy experience at the Eliava Institute. Med Mal Infect. 2008;38(8): 426-30.

57. Hoyle N, Zhvaniya P, Balarjishvili N, Bolkvadze D, Nadareishvili L, Nizharadze D, et al. Phage therapy against Achromobacter xylosoxidans lung infection in a patient with cystic fibrosis: a case report. Res Microbiol. 2018;169(9):540-2.

58. Barbu EM, Cady KC, Hubby B. Phage therapy in the era of synthetic biology. Cold Spring Harbor Perspect Biol. 2016;8(10): a023879.

59. Loh B, Gondil VS, Manohar P, Khan FM, Yang H, Leptihn S. Encapsulation and delivery of therapeutic phages. Appl Environ Microbiol. 2021;87(5): e01979-20.

60. Ryan EM, Gorman SP, Donnelly RF, Gilmore BF. Recent advances in bacteriophage therapy: how delivery routes, formulation, concentration and timing influence the success of phage therapy. J Pharm Pharmacol. 2011;63(10):1253-64.

61. Alsaadi A, Beamud B, Easwaran M, Abdelrahman F, El-Shibiny A, Alghoribi MF, Domingo-Calap P. Learning from mistakes: the role of phages in pandemics. Front Microbiol. 2021;12: 653107.

62. Rangel-Vega A, Bernstein LR, Mandujano Tinoco EA, García-Contreras SJ, García-Contreras R. Drug repurposing as an alternative for the treatment of 
recalcitrant bacterial infections. Front Microbiol. $2015 ; 6: 282$.

63. Miró-Canturri A, Ayerbe-Algaba R, Smani Y. Drug repurposing for the treatment of bacterial and fungal infections. Front Microbiol. 2019;10:41.

64. Pushpakom S, Iorio F, Eyers $\mathrm{P}$, et al. Drug repurposing: progress, challenges and recommendations. Nat Rev Drug Discov. 2019;18:41-58.

65. Ashburn TT, Tor KB. Drug repositioning: identifying and developing new uses for existing drugs. Nat Rev Drug Discov. 2004;3:673-83.

66. Chong CR, Sullivan DJ Jr. New uses for old drugs. Nature. 2007;448:645-6.

67. Sahragardjoonegani B, Beall RF, Kesselheim AS, Hollis A. Repurposing existing drugs for new uses: a cohort study of the frequency of FDA-granted new indication exclusivities since 1997. J Pharm Policy Pract. 2021;14(1):1-8.

68. Farha MA, Brown ED. Drug repurposing for antimicrobial discovery. Nat Microbiol. 2019;4(4): 565-77.

69. Costanzo M, De Giglio MA, Roviello GN. SARS-CoV2: recent reports on antiviral therapies based on lopinavir/ritonavir, darunavir/umifenovir, hydroxychloroquine, remdesivir, favipiravir and other drugs for the treatment of the new coronavirus. Curr Med Chem. 2020;27(27):4536-41.

70. Carlson-Banning KM, Chou A, Liu Z, Hamill RJ, Song Y, Zechiedrich L. Toward repurposing ciclopirox as an antibiotic against drug-resistant Acinetobacter baumannii, Escherichia coli, and Klebsiella pneumoniae. PLoS One. 2013;8: e69646. https://doi. org/10.1371/journal.pone.0069646.

71. Zakaria AS, Edward EA, Mohamed NM. Evaluation of ciclopirox as a virulence-modifying agent against multidrug resistant pseudomonas aeruginosa clinical isolates from Egypt. Microbiol Biotechnol Lett. 2019;47(4):651-61.

72. Hennessy E, Mooij MJ, Legendre C, Reen FJ, O'callaghan J, Adams C, et al. Statins inhibit in vitro virulence phenotypes of Pseudomonas aeruginosa. J Antibiot (Tokyo). 2012;66:99-101. https://doi.org/ 10.1038/ja.2012.95.

73. Rosch JW, Boyd AR, Hinojosa E, Pestina T, Hu Y, Persons DA, et al. Statins protect against fulminant pneumococcal infection and cytolysin toxicity in a mouse model of sickle cell disease. J Clin Investig. 2010;120:627-35. https://doi.org/10.1172/ JCI39843.
74. Singh RP, Hodson DP, Huerta-Espino J, Jin Y, Bhavani S, Njau P, Herrera-Foessel S, Singh PK, Singh S, Govindan V. The emergence of Ug99 races of the stem rust fungus is a threat to world wheat production. Annu Rev Phytopathol. 2011;49:465-81.

75. Holbrook SY, Garzan A, Dennis EK, Shrestha SK, Garneau-Tsodikova S. Repurposing antipsychotic drugs into antifungal agents: synergistic combinations of azoles and bromperidol derivatives in the treatment of various fungal infections. Eur J Med Chem. 2017;139:12-21.

76. Sun W, Park YD, Sugui JA, Fothergill A, Southall N, Shinn P, et al. Rapid identification of antifungal compounds against Exserohilum rostratum using high throughput drug repurposing Screens. PLoS One. 2013;8: e70506. https://doi.org/10.1371/ journal.pone.0070506.

77. Krysan DJ, Didone L. A high-throughput screening assay for small molecules that disrupt yeast cell integrity. J Biomol Screen. 2008;13:657-64.

78. Wiederhold NP, Patterson TF, Srinivasan A, Chaturvedi AK, Fothergill AW, Wormley FL, et al. Repurposing auranofin as an antifungal: in vitro activity against a variety of medically important fungi. Virulence. $2017 ; 8(2): 138-42$.

79. Thangamani S, Maland M, Mohammad H, Pascuzzi PE, Avramova L, Koehler CM, et al. Repurposing approach identifies auranofin with broad spectrum antifungal activity that targets Mia40-Erv1 pathway. Front Cell Infect Microbiol. 2017;7:4.

80. Truong M, Monahan LG, Carter DA, Charles IG. Repurposing drugs to fast-track therapeutic agents for the treatment of cryptococcosis. PeerJ. 2018;6: e4761.

81. Ribeiro NQ, Costa MC, Magalhães TFF, Carneiro HCS, Oliveira LV, Fontes ACL, et al. Atorvastatin as a promising anti cryptococcal agent. Int J Antimicrob Agents. 2017;49:695-702. https://doi.org/10. 1016/j.ijantimicag.2017.04.005.

82. Khodaverdian V, Pesho M, Truitt B, Bollinger L, Patel P, Nithianantham S, et al. Discovery of antivirulence agents against methicillin-resistant Staphylococcus aureus. Antimicrob Agents Chemother. 2013;57(8):3645-52.

83. Oliver WT, Wells JE. Lysozyme as an alternative to growth promoting antibiotics in swine production. J Anim Sci Biotechnol. 2015;6(1):1-7.

84. Gálvez-Iriqui AC, Plascencia-Jatomea M, BautistaBaños S. Lysozymes: characteristics, mechanism of action and technological applications on the control of pathogenic microorganisms. Revista mexicana de fitopatología. 2020;38(3):360-83. 
85. Ibrahim HR, Imazato K, Ono H. Human lysozyme possesses novel antimicrobial peptides within its N-terminal domain that target bacterial respiration. J Agric Food Chem. 2011;59(18):10336-45.

86. Escott GM, Adams DJ. Chitinase activity in human serum and leukocytes. Infect Immun. 1995;63(12): 4770-3.

87. Mehra T, Köberle M, Braunsdorf C, Mailänder-Sanchez D, Borelli C, Schaller M. Alternative approaches to antifungal therapies. Exp Dermatol. 2012;21(10):778-82.

88. Hall AJ, Morroll S, Tighe P, Götz F, Falcone FH. Human chitotriosidase is expressed in the eye and lacrimal gland and has an antimicrobial spectrum different from lysozyme. Microbes Infect. 2008;10(1):69-78.

89. Schimmelpennink MCV, Vorselaars ADM, Grutters JC. Biomarkers in sarcoidosis. Sarcoidosis a clinician's guide, p. 219-38 (2019).

90. Yu C. Lysosomal storage disorders: sphingolipidosis, chapter 10. In: Garg U, Smith LD, editors. Biomarkers in inborn errors of metabolism. Amsterdam: Elsevier; 2017. p. 211-33.

91. Cho WS, Kim TH, Lee HM, Lee SH, Lee SH, Yoo JH, et al. Increased expression of acidic mammalian chitinase and chitotriosidase in the nasal mucosa of patients with allergic rhinitis. Laryngoscope. 2010;120(5):870-5.

92. Samaranayake YH, Samaranayake LP, Wu PC, So M. The antifungal effect of lactoferrin and lysozyme on Candida krusei and Candida albicans. APMIS. 1997;105(7-12):875-83.

93. Fernandes KE, Carter DA. The antifungal activity of lactoferrin and its derived peptides: mechanisms of action and synergy with drugs against fungal pathogens. Front Microbiol. 2017;8:2.

94. Weinberg ED. The therapeutic potential of lactoferrin. Expert Opin Investig Drugs. 2003;12(5): 841-51.

95. Orsi N. The antimicrobial activity of lactoferrin: current status and perspectives. Biometals. 2004;17(3):189-96.

96. Ellepola ANB, Dassanayake RS, Khan Z. Impact of brief exposure to drugs with antifungal properties on the susceptibility of oral candida dubliniensis isolates to lysozyme and lactoferrin. Med Princ Pract. 2018;27(6):523-30.

97. Takakura N, Wakabayashi H, Ishibashi H, Teraguchi S, Tamura Y, Yamaguchi H, Abe S. Oral lactoferrin treatment of experimental oral candidiasis in mice.
Antimicrob Agents Chemother. 2003;47(8): 2619-23.

98. Tomee JC, Hiemstra PS, Heinzel-Wieland R, Kauffman HF. Antileukoprotease: an endogenous protein in the innate mucosal defense against fungi. J Infect Dis. 1997;176(3):740-7.

99. O'Flaherty S, Ross RP, Coffey A. Bacteriophage and their lysins for elimination of infectious bacteria. FEMS Microbiol Rev. 2009;33(4):801-19.

100. Abdelrahman F, Easwaran M, Daramola OI, Ragab S, Lynch S, Oduselu TJ, et al. Phage-encoded endolysins. Antibiotics. 2021;10(2):124.

101. Fenton M, McAuliffe O, O'Mahony J, Coffey A. Recombinant bacteriophage lysins as antibacterials. Bioeng Bugs. 2010;1(1):9-16.

102. Nelson D, Loomis L, Fischetti VA. Prevention and elimination of upper respiratory colonization of mice by group A streptococci by using a bacteriophage lytic enzyme. Proc Natl Acad Sci. 2001;98(7): 4107-12.

103. Fowler VG, Das AF, Lipka-Diamond J, Schuch R, Pomerantz R, Jáuregui-Peredo L, et al. Exebacase for patients with Staphylococcus aureus bloodstream infection and endocarditis. J Clin Investig. 2020;130(7):3750-60.

104. Channabasappa S, Chikkamadaiah R, Durgaiah M, Kumar S, Ramesh K, Sreekanthan A, Sriram B. Efficacy of chimeric ectolysin P128 in drug-resistant Staphylococcus aureus bacteraemia in mice. J Antimicrob Chemother. 2018;73(12):3398-404.

105. Loeffler JM, Djurkovic S, Fischetti VA. Phage lytic enzyme Cpl-1 as a novel antimicrobial for pneumococcal bacteremia. Infect Immun. 2003;71(11): 6199-204.

106. Melo MN, Ferre R, Castanho MA. Antimicrobial peptides: linking partition, activity and high membrane-bound concentrations. Nat Rev Microbiol. 2009;7(3):245-50.

107. Brogden KA. Antimicrobial peptides: pore formers or metabolic inhibitors in bacteria? Nat Rev Microbiol. 2005;3(3):238-50.

108. Leptihn S, Har JY, Wohland T, Ding JL. Correlation of charge, hydrophobicity, and structure with antimicrobial activity of S1 and MIRIAM peptides. Biochemistry. 2010;49(43):9161-70.

109. Leptihn S, Har JY, Chen J, Ho B, Wohland T, Ding JL. Single molecule resolution of the antimicrobial action of quantum dot-labeled sushi peptide on live bacteria. BMC Biol. 2009;7(1):1-13. 
110. Leptihn S, Guo L, Frecer V, Ho B, Ding JL, Wohland T. One step at a time: Action mechanism of Sushi1 antimicrobial peptide and derived molecules. Virulence. 2010;1(1):42-4.

111. Braff MH, Bardan A, Nizet V, Gallo RL. Cutaneous defense mechanisms by antimicrobial peptides. J Investig Dermatol. 2005;125(1):9-13.

112. Jia F, Wang J, Peng J, Zhao P, Kong Z, Wang K, et al. The in vitro, in vivo antifungal activity and the action mode of Jelleine-I against Candida species. Amino Acids. 2018;50(2):229-39.

113. Selsted ME, Ouellette AJ. Mammalian defensins in the antimicrobial immune response. Nat Immunol. 2005;6(6):551-7.

114. Mygind PH, Fischer RL, Schnorr KM, Hansen MT, Sönksen CP, Ludvigsen S, et al. Plectasin is a peptide antibiotic with therapeutic potential from a saprophytic fungus. Nature. 2005;437(7061):975-80.

115. Zhu S. Evidence for myxobacterial origin of eukaryotic defensins. Immunogenetics. 2007;59(12):949-54.

116. Gao B, del Carmen Rodriguez M, Lanz-Mendoza H, Zhu S. AdDLP, a bacterial defensin-like peptide, exhibits anti-Plasmodium activity. Biochem Biophys Res Commun. 2009;387(2):393-8.

117. Krishnakumari V, Rangaraj N, Nagaraj R. Antifungal activities of human beta-defensins HBD-1 to HBD-3 and their C-terminal analogs Phd1 to Phd3. Antimicrob Agents Chemother. 2009;53(1):256-60.

118. Thevissen K, Kristensen HH, Thomma BP, Cammue BP, Francois IE. Therapeutic potential of antifungal plant and insect defensins. Drug Discov Today. 2007;12(21-22):966-71.

119. McCormick TS, Weinberg A. Epithelial cell-derived antimicrobial peptides are multi-functional agents that bridge innate and adaptive immunity. Periodontol. 2010. https://doi.org/10.1111/j.16000757.2010.00373.x.

120. López-García B, Lee PH, Yamasaki K, Gallo RL. Antifungal activity of cathelicidins and their potential role in Candida albicans skin infection. J Investig Dermatol. 2005;125(1):108-15.

121. Benincasa M, Scocchi M, Pacor S, Tossi A, Nobili D, Basaglia G, et al. Fungicidal activity of five cathelicidin peptides against clinically isolated yeasts. J Antimicrob Chemother. 2006;58(5):950-9.

122. Schittek B, Hipfel R, Sauer B, Bauer J, Kalbacher H, Stevanovic S, et al. Dermcidin: a novel human antibiotic peptide secreted by sweat glands. Nat Immunol. 2001;2(12):1133-7.
123. Wagener J, Schneider JJ, Baxmann S, Kalbacher H, Borelli C, Nuding S, et al. A peptide derived from the highly conserved protein GAPDH is involved in tissue protection by different antifungal strategies and epithelial immunomodulation. J Investig Dermatol. 2013;133(1):144-53.

124. Kamysz W, Nadolski P, Kedzia A, Cirioni O, Barchiesi F, Giacometti A, et al. In vitro activity of synthetic antimicrobial peptides against Candida. Pol J Microbiol. 2006;55(4):303-7.

125. Maurya IK, Pathak S, Sharma M, Sanwal H, Chaudhary $P$, Tupe $S$, et al. Antifungal activity of novel synthetic peptides by accumulation of reactive oxygen species (ROS) and disruption of cell wall against Candida albicans. Peptides. 2011;32(8): 1732-40.

126. Semlali A, Leung KP, Curt S, Rouabhia M. Antimicrobial decapeptide KSL-W attenuates Candida albicans virulence by modulating its effects on Tolllike receptor, human $\beta$-defensin, and cytokine expression by engineered human oral mucosa. Peptides. 2011;32(5):859-67.

127. Cloete TE. Resistance mechanisms of bacteria to antimicrobial compounds. Int Biodeterior Biodegrad. $2003 ; 51(4): 277-82$.

128. Lim CS, Ha KP, Clarke RS, Gavin LA, Cook DT, Hutton JA, et al. Identification of a potent smallmolecule inhibitor of bacterial DNA repair that potentiates quinolone antibiotic activity in methicillin-resistant Staphylococcus aureus. Bioorg Med Chem. 2019;27(20): 114962.

129. Srinivas N, Jetter P, Ueberbacher BJ, Werneburg M, Zerbe K, Steinmann J, Van Der Meijden B, Bernardini F, Lederer A, Dias RL, et al. Peptidomimetic antibiotics target outer-membrane biogenesis in Pseudomonas aeruginosa. Science. 2010;327:1010-3.

130. Matos de Opitz CL, Sass P. Tackling antimicrobial resistance by exploring new mechanisms of antibiotic action. Future Microbiol. 2020;15:703-8.

131. Shehaj L, Choudary SK, Makwana KM, Gallo MC, Murphy TF, Kritzer JA. Small-molecule inhibitors of Haemophilus influenzae IgA1 protease. ACS Infect Dis. 2019;5(7):1129-38.

132. Maffioli SI, Zhang Y, Degen D, Carzaniga T, Del Gatto G, Serina S, Monciardini P, Mazzetti C, Guglierame P, Candiani G, et al. Antibacterial nucleoside-analog inhibitor of bacterial RNA polymerase. Cell. 2017;169:1240-8.

133. Thomson JM, Lamont IL. Nucleoside analogues as antibacterial agents. Front Microbiol. 2019;10:952. 
134. Xue A, Robbins N, Cowen LE. Advances in fungal chemical genomics for the discovery of new antifungal agents. Ann N Y Acad Sci. 2021;1496:5-22.

135. Fedorova O, Jagdmann GE, Adams RL, et al. Small molecules that target group II introns are potent antifungal agents. Nat Chem Biol. 2018;14:1073-8.

136. Wong SSW, Kao RYT, Yuen KY, Wang Y, Yang D, Samaranayake LP, Seneviratne CJ. In vitro and in vivo activity of a novel antifungal small molecule against Candida infections. PLoS One. 2014;9(1): e85836.

137. Shareck J, Belhumeur P. Modulation of morphogenesis in Candida albicans by various small molecules. Eukaryot Cell. 2011;10(8):1004-12.

138. Yah CS, Simate GS. Nanoparticles as potential new generation broad spectrum antimicrobial agents. DARU J Pharm Sci. 2015;23(1):43.

139. Koskella B, Brockhurst MA. Bacteria-phage coevolution as a driver of ecological and evolutionary processes in microbial communities. FEMS Microbiol Rev. 2014;38(5):916-31.

140. Vázquez R, García E, García P. Phage lysins for fighting bacterial respiratory infections: a new generation of antimicrobials. Front Immunol. 2018;9:2252.

141. Manohar P, Loh B, Athira S, Nachimuthu R, Hua X, Welburn SC, Leptihn S. Secondary bacterial infections during pulmonary viral disease: phage therapeutics as alternatives to antibiotics? Front Microbiol. 2020;11:1434.

142. Davies J. Where have all the antibiotics gone? Can J Infect Dis Med Microbiol. 2006;17:287-90.

143. Khan I, Saeed K, Khan I. Nanoparticles: properties, applications and toxicities. Arab J Chem. 2019;12(7):908-31.

144. Gill R, Babu VAM, Kumari KM. Assets and liabilities of drug repositioning. Int $\mathrm{J}$ Pharm Bio Sci. 2016;7(4):P47-53.

145. Nicolas I, Bordeau V, Bondon A, Baudy-Floc'h M, Felden B. Novel antibiotics effective against grampositive and-negative multi-resistant bacteria with limited resistance. PLoS Biol. 2019;17(7): e3000337.

146. Gupta C, Prakash D. Dermcidin: a natural antibiotic of therapeutic importance. Diagn Ther Complement Tradit Med. 2020;1:22-4.
147. Guzman M, Dille J, Godet S. Synthesis and antibacterial activity of silver nanoparticles against gram-positive and gram-negative bacteria. Nanomed Nanotechnol Biol Med. 2012;8(1):37-45.

148. Harper DR, Parracho HM, Walker J, Sharp R, Hughes $\mathrm{G}$, Werthén $\mathrm{M}$, et al. Bacteriophages and biofilms. Antibiotics. 2014;3(3):270-84.

149. Park S, Jun SY, Kim CH, Jung GM, Son JS, Jeong ST, et al. Characterisation of the antibacterial properties of the recombinant phage endolysins AP50-31 and LysB4 as potent bactericidal agents against Bacillus anthracis. Sci Rep. 2018;8(1):18.

150. Rajamuthiah R, Fuchs BB, Conery AL, Kim W, Jayamani E, Kwon B, et al. Repurposing salicylanilide anthelmintic drugs to combat drug resistant Staphylococcus aureus. PLoS One. 2015;10(4): e0124595.

151. Kraemer SA, Ramachandran A, Perron GG. Antibiotic pollution in the environment: from microbial ecology to public policy. Microorganisms. 2019;7(6):180.

152. Yu SJ, Yin YG, Liu JF. Silver nanoparticles in the environment. Environ Sci Process Impacts. 2013;15(1):78-92.

153. Loc-Carrillo C, Abedon ST. Pros and cons of phage therapy. Bacteriophage. 2011;1(2):111-4.

154. Boxall $\mathrm{AB}$. The environmental side effects of medication: how are human and veterinary medicines in soils and water bodies affecting human and environmental health? EMBO Rep. 2004;5(12):1110-6.

155. Vicente $\mathrm{M}$, Hodgson J, Massidda O, Tonjum T, Henriques-Normark B, Ron EZ. The fallacies of hope: will we discover new antibiotics to combat pathogenic bacteria in time? FEMS Microbiol Rev. 2006;30(6):841-52.

156. Prasad R. Synthesis of silver nanoparticles in photosynthetic plants. J Nanopart. 2014. https://doi. org/10.1155/2014/963961.

157. Kamaya T. Lytic action of lysozyme on Candida albicans. Mycopathol Mycol Appl. 1970;42(3-4): 197-207.

158. Kanafani ZA, Perfect JR. Resistance to antifungal agents: mechanisms and clinical impact. Clin Infect Dis. 2008;46(1):120-8.

159. Imperi F, Massai F, Ramachandran Pillai C, Longo F, Zennaro E, Rampioni G, et al. New life for an old 
drug: the anthelmintic drug niclosamide inhibits Pseudomonas aeruginosa quorum sensing. Antimicrob Agents Chemother. 2013;57:996-1005. https://doi.org/10.1128/AAC.01952-12.

160. Munoz-Bellido JL, Munoz-Criado S, García-Rodríguez JA. Antimicrobial activity of psychotropic drugs selective serotonin reuptake inhibitors. Int J Antimicrob Agents. 2000;14:177-80.

161. Jung EH, Meyers DJ, Bosch J, Casadevall A. Novel antifungal compounds discovered in medicines for malaria venture's malaria box. mSphere. 2018;3: e537-17. https://doi.org/10.1128/mSphere.0053717. 